\title{
A systematic review of hip fracture incidence and probability of fracture worldwide
}

\author{
J. A. Kanis • A. Odén • E. V. McCloskey • H. Johansson • \\ D. A. Wahl • C. Cooper . \\ on behalf of the IOF Working Group on Epidemiology \\ and Quality of Life
}

Received: 21 February 2012 / Accepted: 21 February 2012 / Published online: 15 March 2012

(C) International Osteoporosis Foundation and National Osteoporosis Foundation 2012

\begin{abstract}
Summary The country-specific risk of hip fracture and the 10-year probability of a major osteoporotic fracture were determined on a worldwide basis from a systematic review of literature. There was a greater than 10 -fold variation in hip fracture risk and fracture probability between countries. Introduction The present study aimed to update the available information base available on the heterogeneity in the risk of hip fracture on a worldwide basis. An additional aim was to document variations in major fracture probability as determined from the available FRAX models.

Methods Studies on hip fracture risk were identified from 1950 to November 2011 by a Medline OVID search.
\end{abstract}

The members of the IOF Working Group on Epidemiology and Quality of Life are Adachi J, Borgström F, Clark P, Cooper C, Cummings S, Diaz Curiel M, Dimai HP, Hiligsmann M, Kanis JA, Lau E, Lewiecki EM, Lips P, Lorenc R, McCloskey E, Ortolani S, Papaioannou A, Silverman S, Yoshimura N, and Szulc P.

J. A. Kanis $(\varangle) \cdot$ A. Odén $\cdot$ E. V. McCloskey $\cdot$ H. Johansson WHO Collaborating Centre for Metabolic Bone Diseases,

University of Sheffield Medical School,

Beech Hill Road,

Sheffield S10 2RX, UK

e-mail: w.j.pontefract@sheffield.ac.uk

D. A. Wahl

International Osteoporosis Foundation,

Nyon, Switzerland

C. Cooper

MRC Lifecourse Epidemiology Unit,

University of Southampton and NIHR Musculoskeletal

Biomedical Research Unit, University of Oxford,

Oxford, UK
Evaluable studies in each country were reviewed for quality and representativeness and a study (studies) chosen to represent that country. Age-specific incidence rates were agestandardised to the world population in 2010 in men, women and both sexes combined. The 10-year probability of a major osteoporotic fracture for a specific clinical scenario was computed in those countries for which a FRAX model was available.

Results Following quality evaluation, age-standardised rates of hip fracture were available for 63 countries and 45 FRAX models available in 40 countries to determine fracture probability. There was a greater than 10 -fold variation in hip fracture risk and fracture probability between countries.

Conclusions Worldwide, there are marked variations in hip fracture rates and in the 10 -year probability of major osteoporotic fractures. The variation is sufficiently large that these cannot be explained by the often multiple sources of error in the ascertainment of cases or the catchment population. Understanding the reasons for this heterogeneity may lead to global strategies for the prevention of fractures.

Keywords Fracture probability · FRAX · Hip fracture incidence $\cdot$ Hip fracture risk $\cdot$ Osteoporosis

\section{Introduction}

The clinical manifestation of osteoporosis is in the fractures that arise. Hip fractures are a useful surrogate for determining the international burden of osteoporosis. Although they account for less than $20 \%$ of all osteoporotic fractures [1,2], they account for the majority of fracture-related health care 
expenditure and mortality in men and women over the age of 50 years [1-4]. In addition, the vast majority of hip fracture cases come to medical attention and require hospital facilities. As a result, much more is known of the epidemiology of hip fracture than for other fractures associated with osteoporosis.

A variety of studies have examined hip fracture rates in different regions of the world [5-11]. Greater than 10 -fold differences have been found, largely on the basis of register studies undertaken on a regional or national level and at different calendar years. The aim of the present study was to provide the most accurate assessment of hip fracture risk in all countries for which data were available. In addition, we wished to examine the heterogeneity of major fracture probability in those countries where a FRAX model was available.

\section{Methods}

\section{Literature survey}

We updated a systematic search conducted by Cauley et al. on behalf of the International Task Force for the ISCD IOF FRAX Initiative [12, 13]. This was a Medline OVID search covered between 1 January 1950 and 10 May 2010. Details regarding the search strategy and $\mathrm{MeSH}$ terms used are provided in Cauley et al. [12, 13]. The three primary concepts were: fracture, incidence and the country or their related terms. The three concepts were searched singly, and then merged together through the AND term. The information base was updated by the International Osteoporosis Foundation using the same search terms with a cut-off date of 7 November 2011. Additional sources were reviews by Kanis et al. [14] and Cheng et al. [5]. We also supplemented this search by handsearching the references of all papers to identify any additional articles of interest. In several instances additional information was provided by the authors of papers to aid in the assessment of study quality or to provide additional detail not reported in the original publication.

\section{Exclusion and inclusion criteria}

Abstracts and full papers identified by the search were reviewed. We included non-English articles. All papers that reported age- and sex-specific incidence rates of hip fracture in a general population were eligible for a more detailed review. Further exclusion criteria comprised data that could not be standardised to the world population (age categories incomplete from the age of 50 years or age categories $>10$ years), an uncertain population base or illdefined cases.

For the remaining studies, a quality assessment, originally developed by Cauley et al. [13], was adapted to provide three grades:

Good: Evidence includes consistent results from welldesigned, well-conducted studies in representative populations. Selection of hip fracture cases was based on health care records, and the methodology was well described. At least four of the following criteria should be met: prospective study, study population representative of the entire population, study duration of 1 year or more and adequate definition of fracture or use of ICD codes, ethnicities defined when applicable.

Fair: Evidence is sufficient to determine effects on outcomes, but the strength of the evidence is limited by the number, quality or consistency of the individual studies, i.e. studies that did not meet the criteria for either good or poor and met some but not all quality criteria.

Poor: Evidence is insufficient to assess the effects on outcomes because of limited number or power of studies, important flaws in their design or conduct, gaps in the chain of evidence or lack of information. Criteria were: a retrospective study, study duration of less than 1 year, not population based, inadequate definition of fracture and abstract only available or no definition of ethnicities provided where relevant.

Where assessment was not possible, the study was discarded.

\section{Selection criteria}

From the publications available, one dataset was chosen to characterise hip fracture risk in that country which could be a single study or the mean of several studies where appropriate. Criteria for selecting a study or studies over others to represent a country are listed below and details are provided in the Appendix.

1. FRAX model available

2. National rather than regional data

3. Higher quality

4. Most recent study

5. Mean of several regional estimates

6. Sole study available

7. Additional details supplied by the author, see notes in tables 
Where a FRAX model was available for a particular country, the hip fracture rates used for FRAX were selected since these used recent data were available and had been vetted previously for quality or consistency [13, 14]. Notwithstanding, recent publications, appearing between May 2010 and November 2011 (search cut-off dates) were reviewed to determine the adequacy of the data used for the FRAX models. In the case of China, more recent regional data had been published [15] and were preferentially selected for this report. For Belgium, we used more extensive national estimates (2005-2007 rather than 2006) supplied by the same author [16, 17], M Hiligsmann 2011, personal communication]. For Italy, we used recent national data for 2007 [18] rather than the four regional estimates used in FRAX (version 3.4) [14].

In the absence of a FRAX model, national studies were preferred over regional estimates. For regional estimates, the most recent and higher quality studies were preferred. In four instances, several studies of comparable quality were available and we used the mean value of these estimates (Brazil, four estimates [10, 19-21]; Croatia, three estimates in two reports [22, 23]; Greece, three estimates [9, 24, 25]; Russia, two studies [26] Olga Yershova and Olga Lesnyak 2010, personal communication]; Poland, three studies [27, 28] Edward Czerwinski and Roman Lorenc 2011, personal communication] and Spain, five estimates [14]). For Argentina, China, Iran, Malaysia, Morocco, Norway, Poland, Sweden, Thailand and the UK, we used a single regional estimate but in each instance a review of alternate sources showed that the estimate we chose did not substantially differ from alternate estimates. Sources of information are given in Table 3 of the Appendix.

\section{Data analysis}

Incidence (rates $/ 100,000)$ was assembled by age and by sex. Where possible, 5-year age categories were used. Where 5year age intervals were not available, 10-year intervals were used (intervals of greater than 10 years were an exclusion criterion). For each country, age- and sex-specific rates were used to compute age-adjusted incidence of hip fracture in men, women and men and women combined adjusted to the world population. UN data were used for population demography in 5-year groups for the year 2010 [29]. In the case of Singapore and USA, hip fracture rates were available by ethnic origin. For the purposes of this study, populationweighted means were used and applied to the total population on the recommendation of the Working Group of the IOF Committee of Scientific Advisors. For Israel, incidence was available by race in a single study and a populationweighted mean was used [30]. A total of 72 studies from 63 countries were selected for the calculation of standardised incidence. Details of each study are given in Table 3 of the Appendix.

\section{Probability estimates}

For those countries where a FRAX model was available, we computed the 10-year probability of a major osteoporotic fracture (hip, clinical vertebral, forearm or humeral fracture) using version 3.5 of FRAX (http://www.shef.ac.uk/FRAX/). Since FRAX provides individual rather than populationbased probabilities, we chose the clinical scenario of an individual aged 65 years with a prior fragility fracture (and no other clinical risk factors) at the threshold of osteoporosis as judged by BMD at the femoral neck (i.e. a T-score of -2.5 $\mathrm{SD})$. The body mass index was set at $24 \mathrm{~kg} / \mathrm{m}^{2}$. Estimates were made for men and women. Note that the T-score in men is calculated using the same reference range as that used in women.

As of November 2011, 45 FRAX calculators were available for the 40 countries listed in Table 1 . Note that five models (flagged in Table 1) were not yet published at the cut-off date but were released online at the beginning of 2012 . One of these was a surrogate model (Sri Lanka) derived from the fracture hazard of expatriate Indians living in Singapore and the death hazard for Sri Lanka. The models for Belgium, Czech Republic, Lebanon and Italy were updated with improved or more recent epidemiology and were also released online at the start of 2012. For USA and Singapore, fracture probabilities were available by ethnic origin. For the purposes of this study, means were used weighted by population size in addition to ethnic-specific probabilities.

Table 1 FRAX models available

\begin{tabular}{|c|c|}
\hline Region & Country \\
\hline Asia & $\begin{array}{l}\text { China, Hong Kong, Japan, Philippines, Russian } \\
\text { Federation }^{\text {a }} \text {, South Korea, Singapore } \\
\text { (models for Chinese Malay and Indian ethnicities), }_{\text {Sri Lanka (surrogate) a and Taiwan }}\end{array}$ \\
\hline Europe & $\begin{array}{l}\text { Austria, Belgium }{ }^{\mathrm{b}} \text {, Czech Republic }{ }^{\mathrm{b}} \text {, Denmark, } \\
\text { Finland, France, Germany, Hungary, Italy }{ }^{\mathrm{b}} \text {, } \\
\text { Malta, Netherlands, Norway }{ }^{\mathrm{a}} \text {, Poland, Romania, } \\
\text { Slovakia }^{\mathrm{a}} \text {, Spain, Sweden, Switzerland and UK }\end{array}$ \\
\hline Middle East & Jordan, Lebanon ${ }^{\mathrm{b}}$, Tunisia and Turkey \\
\hline North America & $\begin{array}{l}\text { Canada, Mexico and the US (separate Caucasian, } \\
\text { Black, Hispanic, and Asian calculators available) }\end{array}$ \\
\hline Latin America & Argentina, Colombia and Ecuador ${ }^{\mathrm{a}}$ \\
\hline Oceania & Australia and New Zealand \\
\hline
\end{tabular}

${ }^{\text {a }}$ New model, online January 2012

${ }^{\mathrm{b}}$ Updated model, online January 2012 
Table 2 Categorisation and colour coding for world standardised annual hip fracture rates $(/ 100,000)$ in men, women and both sexes combined

\begin{tabular}{llccccc}
\hline & & & \multicolumn{2}{c}{ Incidence $/ 100,000$} & \multicolumn{2}{c}{ FRAX probability $(\%)$} \\
Colour & Category & Women & Men & Men and women & Men & Women \\
\hline Red & High & $>300$ & $150+$ & $>250$ & $>15$ & $>15$ \\
Orange & Moderate & $200-300$ & $100-150$ & $150-250$ & $10-15$ & $10-15$ \\
Green & Low & $<200$ & $<100$ & $<150$ & $<10$ & $<10$ \\
\hline
\end{tabular}

Additional categories for 10-year probabilities of a major fracture are also given

\section{Colour coding}

For the purposes of cartography, we colour coded hip fracture incidence according to categories of risk designated as

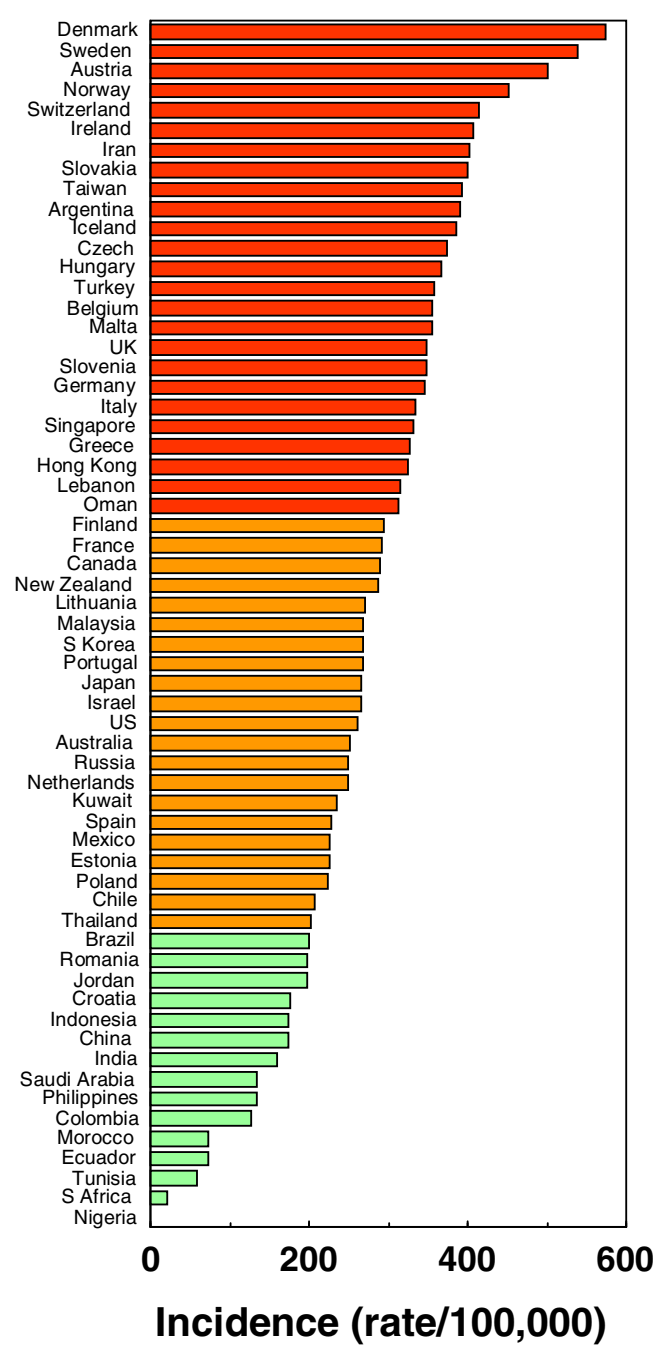

Fig. 1 Age-standardised annual incidence of hip fractures in women $(/ 100,000)$ according to country together with the colour codes high, medium or low (red, orange or green, respectively) in men, women and men and women combined. The risk categories were arbitrary but selected to approximate tertiles of the distribution (Table 2). For categories of fracture probability, we used the same thresholds for men and women.

\section{Results}

Hip fracture risk

A total of 72 studies from 63 countries were selected for inclusion into the hip fracture resource. Studies selected are summarised in Tables 4, 5 and 6 of the Appendix together with the selection criteria and quality grades. There was a marked heterogeneity in hip fracture risk between countries. In women (Fig. 1), the lowest annual age-standardised incidences were found in Nigeria

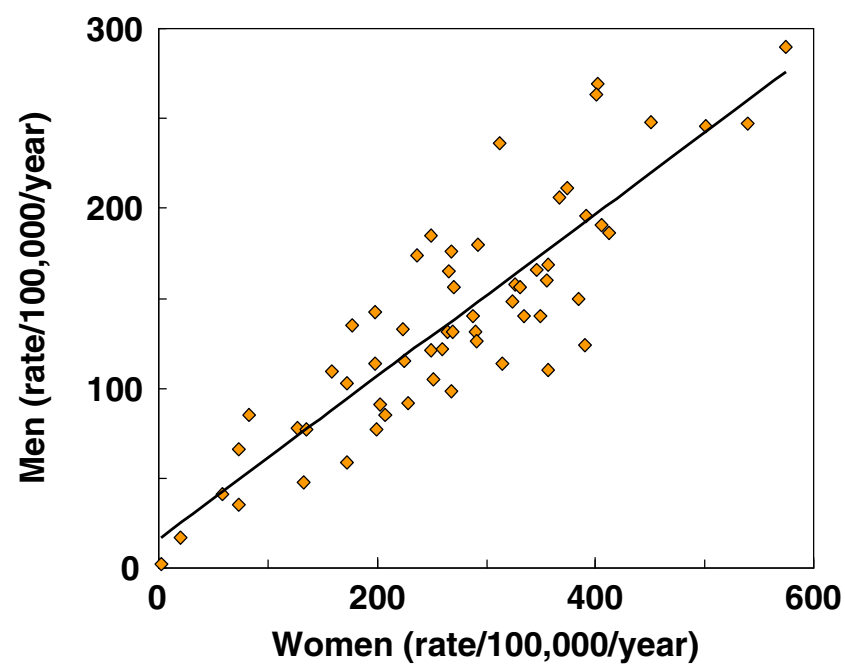

Fig. 2 World standardised hip fracture rates $(/ 100,000 /$ year) in men and women 


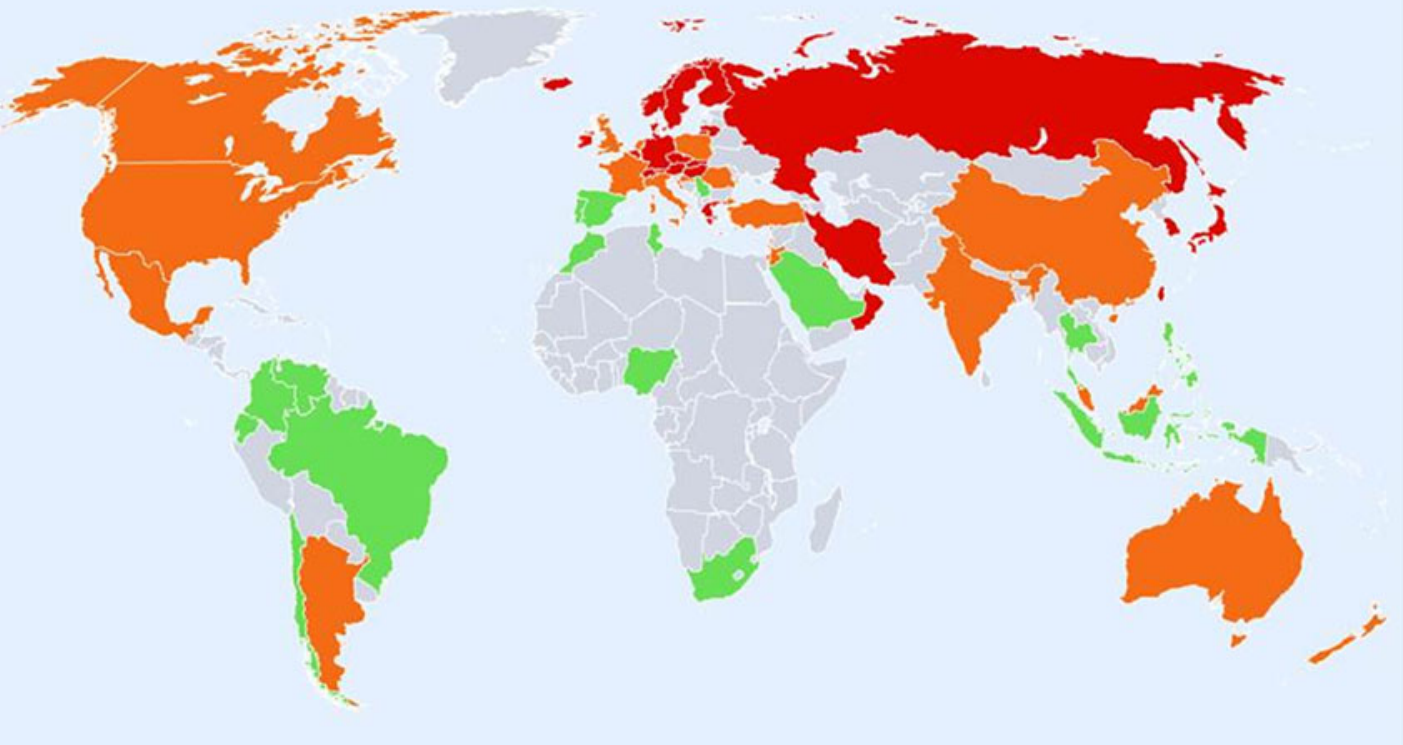

Fig. 3 Hip fracture rates for men in different countries of the world categorised by risk. Where estimates are available, countries are colour coded red (annual incidence $>150 / 100,000)$, orange $(100-150 / 100,000)$ or green $(<100 / 100,000)$

$(2 / 100,000)$, South Africa (20), Tunisia (58) and Ecuador (73). The highest rates were observed in Denmark (574/100,000), Norway (563), Sweden (539) and Austria
(501). Numerical data for other countries are given in Tables 4, 5 and 6 of the Appendix. Discounting the estimates from Nigeria (poor quality) and South Africa

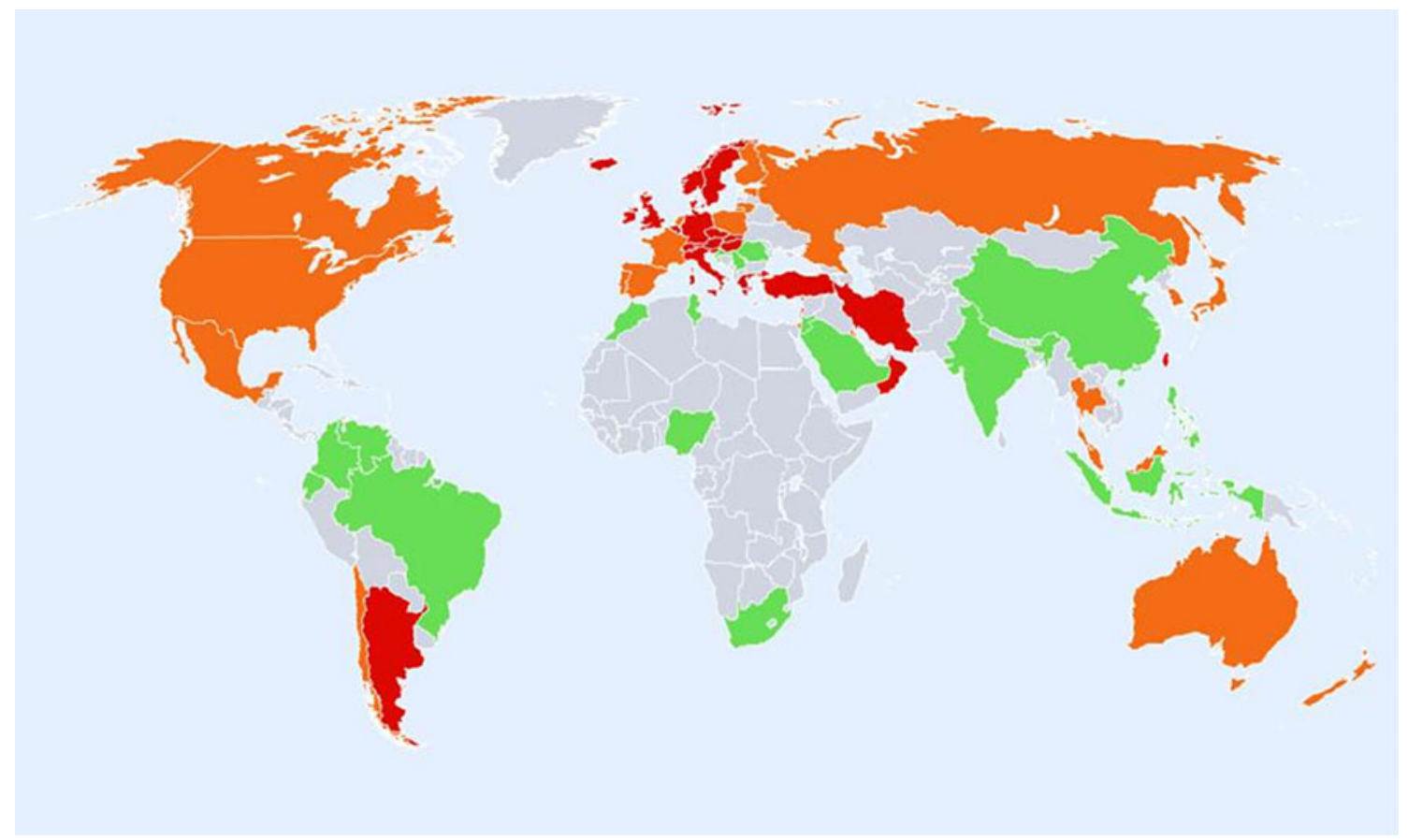

Fig. 4 Hip fracture rates for women in different countries of the world categorised by risk. Where estimates are available, countries are colour coded red (annual incidence $>300 / 100,000)$, orange $(200-300 / 100,000)$ or green $(<200 / 100,000)$ 


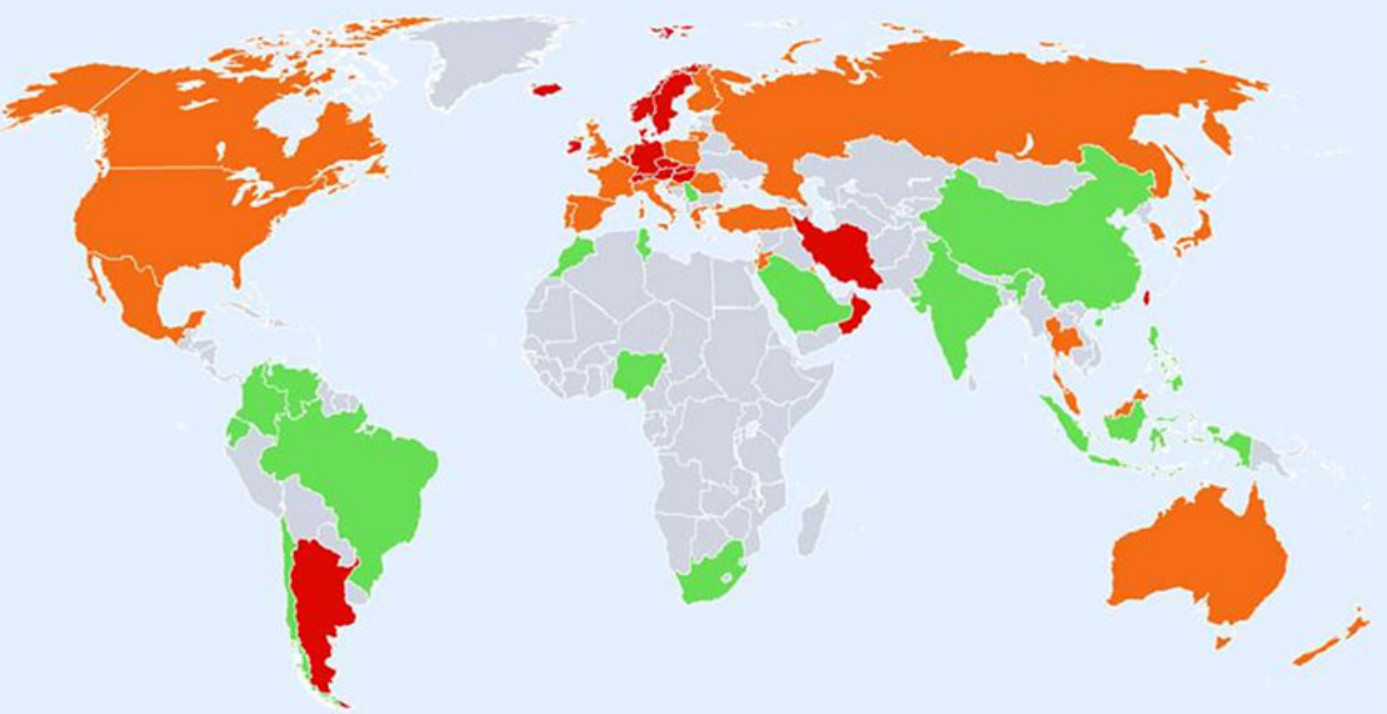

Fig. 5 Hip fracture rates for men and women combined in different countries of the world categorised by risk. Where estimates are available, countries are colour coded red (annual incidence $>250 / 100,000)$, orange $(150-250 / 100,000)$ or green $(<150 / 100,000)$

(rates for 1957-1963), there was approximately a 10fold range in hip fracture incidence.

Within countries, the age-standardised incidence of hip fracture in men was approximately half that noted in women (Fig. 2). Thus where higher rates were observed in women, higher rates were found in men and vice versa. Omitting the studies from Africa, the highest annual incidence in men was seen in Denmark (290/ $100,000)$ and the lowest in Ecuador $(35 / 100,000)$. There was a significant correlation between the rates in men and women $(r=0.82 ; p<0.001)$. The correlation was similar when only high quality studies or only national studies were considered (data not shown).

The geographic distribution by fracture risk is shown for men, women and men and women combined in Figs. 3, 4 and 5, respectively. In men (Fig. 3), there was a swathe of high-risk countries extending from North Western Europe (Iceland, Ireland, Finland, Denmark, Sweden and Norway), both eastwards to the Russian Federation and downwards through to central Europe (Belgium, Germany, Austria and Switzerland) and thereafter to the south west (Greece, Hungary, Czech Republic and Slovakia) and onwards to Iran, Kuwait and Oman. Other high-risk countries for men were Singapore, Malta, Japan, Korea and Taiwan.

Regions of moderate risk included Oceania, China and India, Argentina and the countries of North America. If ethnic-specific rates were considered in USA, then the
Hispanic, Asian and Black populations of men would be colour coded green. Low-risk countries included Latin America with the exception of Argentina, Africa and Saudi Arabia, the Iberian Peninsula and two countries in South East Asia (Indonesia and Thailand).

In women there was a broadly similar pattern as that seen in men. A notable difference in the distribution of high risk was that Russia was represented as moderate risk in women rather than high risk (in men). Also, the swathe of high-risk countries in Europe and beyond was more consolidated extending from North Western Europe (Iceland, UK, Ireland, Denmark, Sweden and Norway) through to central Europe (Belgium, Germany, Austria and Switzerland Italy) and thereafter to the south west (Greece, Hungary, Czech Republic, Slovakia, Slovenia) and onwards to Lebanon, Oman and Iran. Other high-risk countries for women were Hong Kong, Singapore, Malta and Taiwan. If ethnic-specific rates were considered in USA, then Hispanic, Asian and Black populations would be colour coded green but Caucasian women coded at high risk.

Regions of moderate risk included Oceania, the Russian Federation, the southern countries of Latin America and the countries of North America. Low-risk regions included the northern regions of Latin America, Africa, Jordan and Saudi Arabia, India, China, Indonesia and the Philippines. It is notable that in Europe, the majority of countries were 
Fig. 6 Ten-year probability of a major fracture (in percent) in men and women aged 65 years with a prior fragility fracture (and no other clinical risk factors) at the threshold of osteoporosis as judged by BMD at the femoral neck (i.e. a Tscore of $-2.5 \mathrm{SD}$ ). The body mass index was set at $24 \mathrm{~kg} / \mathrm{m}^{2}$

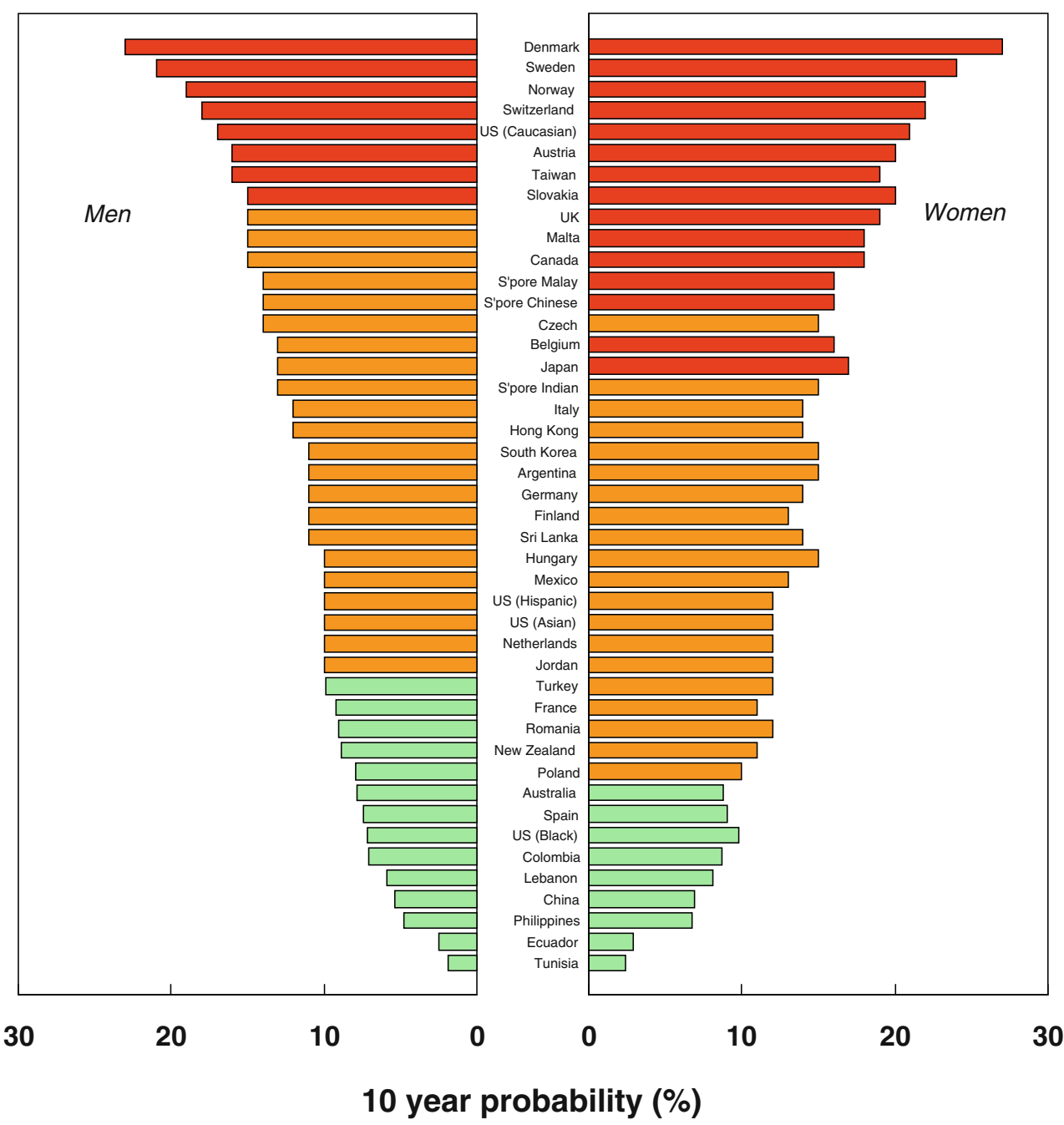

30 categorised at high or moderate risk. Low risk was identified only in Croatia and Romania.

The consolidated map using age- and sex-standardised hip fracture rates is shown in Fig. 5. Note that the thresholds for categories of risk differ from those used in men and those used in women (which also differ from each othersee Table 1). With this proviso, the general pattern remained similar. Discordances in classification were relatively few. In the consolidated map, two countries coded low risk had been previously coded at intermediate risk (men in India and China). At the other extreme, one country coded as high risk had been previously coded at intermediate risk (men and women in Argentina).

As might be expected, there were more discordances in the moderate risk category. Six countries coded at moderate risk had been previously coded at low risk (men in Portugal, Thailand and Spain; women in Croatia, Jordan and Romania). Twelve countries coded at moderate risk had been previously coded at high risk (women in Hong Kong, Turkey, Italy, Lebanon and the UK; men in Kuwait, Japan, Russia, South Korea and Finland; men and women from Greece and Singapore).

\section{FRAX}

A total of 45 country and/or ethnic models were available for inclusion into the distribution of fracture probability. The FRAX models used are summarised in Table 7 of the Appendix. There was a marked heterogeneity in the 10 -year probability of a major fracture between countries. In men (Fig. 6), the lowest probabilities were found in Tunisia (1.9\%), Ecuador (2.5\%), Philippines (4.8\%) and China (5.4\%). The highest rates were observed in Denmark (23\%), Sweden (21\%), Norway (19\%) and Switzerland (18\%). Numerical data for other countries is given in Table 7 of the Appendix. Thus, there was a greater than 10-fold range in fracture probability.

Fracture probabilities were consistently higher in women than in men but the difference was relatively 


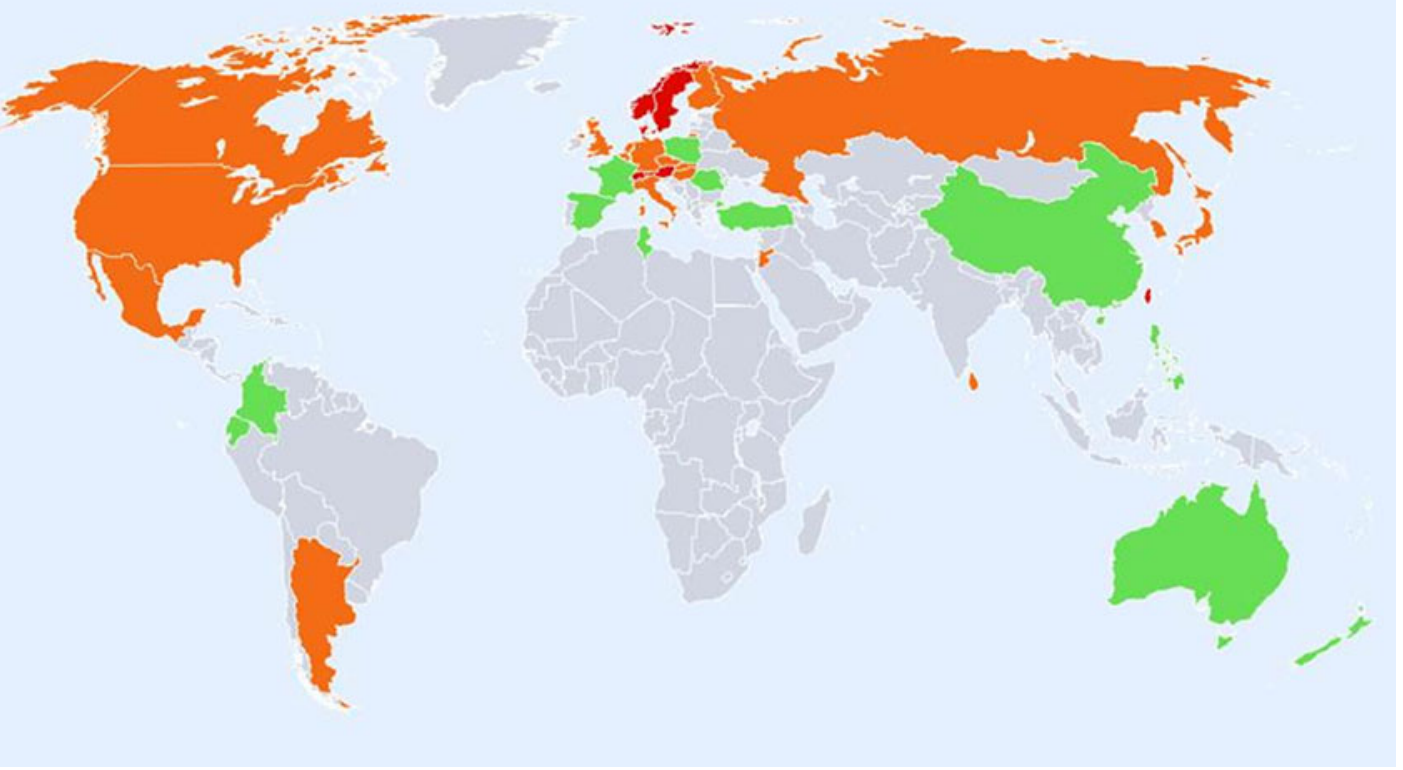

Fig. 7 Ten year probability of a major osteoporotic fracture for a man aged 65 years with a prior fragility fracture (and no other clinical risk factors) at the threshold of osteoporosis as judged by BMD at the femoral neck (i.e. a T-score of -2.5 SD). Probability in different countries is categorised as high ( $\mathrm{red},>15 \%$ ), moderate (orange, 10 $15 \%$ ) and low (green, $<10 \%$ )

between probabilities in men and those in women $(r=$ $0.88 ; p<0.001)$.

The geographic distribution by fracture risk is shown in men and women in Figs. 7 and 8, respectively. High-risk

than in men. As expected, there was a close correlation

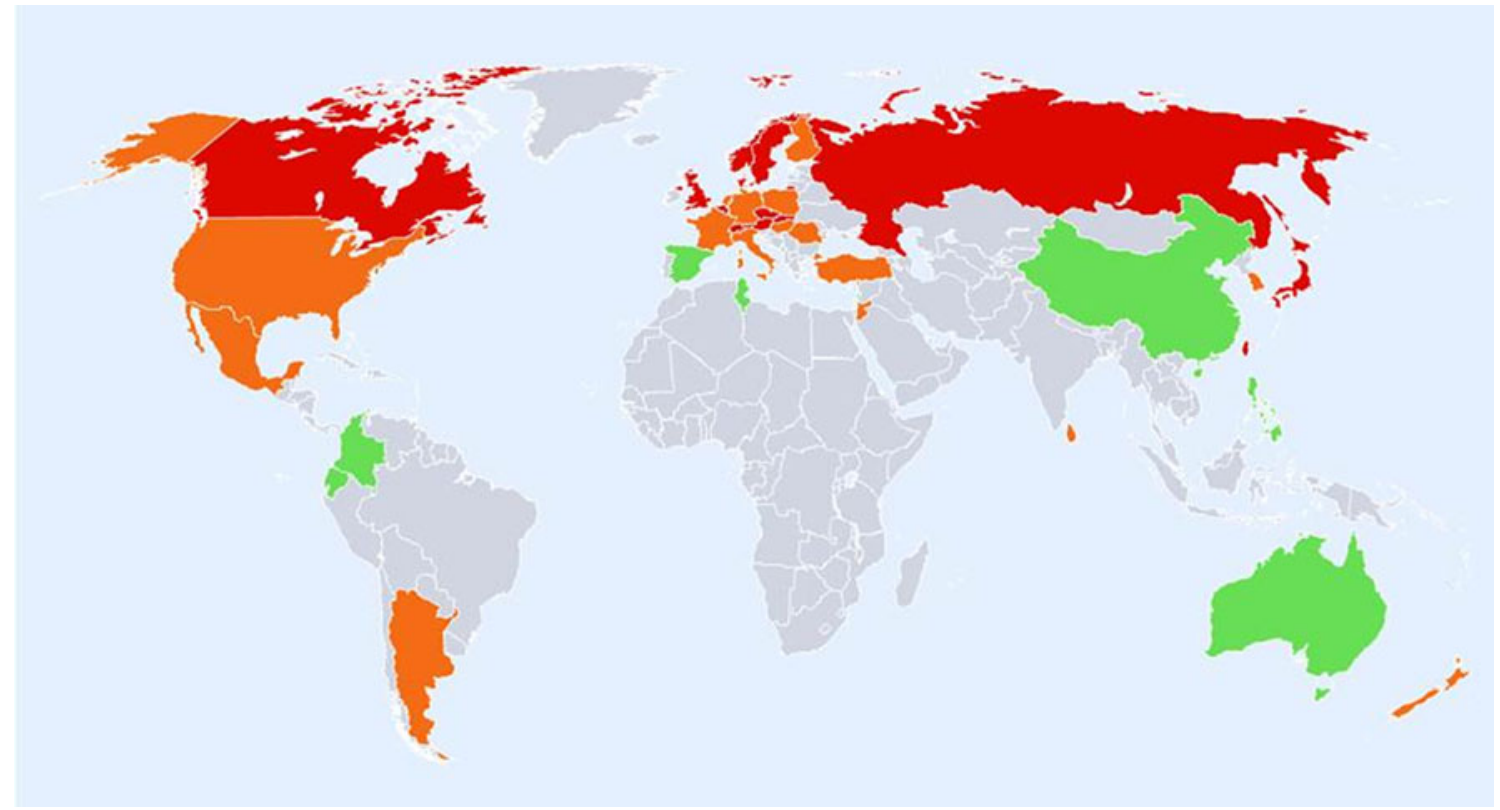

Fig. 8 Ten-year probability of a major osteoporotic fracture for a woman aged 65 years with a prior fragility fracture (and no other clinical risk factors) at the threshold of osteoporosis as judged by
BMD at the femoral neck (i.e. a T-score of -2.5 SD). Probability in different countries is categorised as high ( $\mathrm{red},>15 \%)$, moderate (orange, 10-15\%) and low (green, $<10 \%$ ) 
regions for men were Taiwan, Austria, USA (Caucasian), Switzerland, Norway, Sweden and Denmark. Those at low risk included Africa (Tunisia), Oceania, the Latin American countries of Ecuador and Colombia and several European countries (Spain, Poland, Romania, France and Turkey). Other countries at low risk were China, Lebanon, Philippines and the US Black population.

The general pattern of fracture probability in women was similar to that in men (Fig. 8). Discordances in classification were relatively few. Five countries coded as low risk in men were at intermediate risk for women (Poland, New Zealand, Romania, France and Turkey). Seven countries coded as moderate risk in men were coded at high risk in women (Japan, Belgium, Singapore, Canada, Malta, UK and Slovakia).

\section{Discussion}

The principal finding of the present study is that there is a remarkable variation in the risk of hip fracture worldwide. Age-standardised rates varied approximately 10 -fold in both men and women. The difference in incidence between countries was much greater than the differences in incidence between sexes within a country. These findings confirm conclusions derived from earlier work [5-10, 31] but extend the information base considerably. Whereas a recently published structured review provided information on 32 countries [5], the present systematic review identified 62 countries for which hip fracture rates were available. The greater capture of information provides a more detailed map on which to place ecological patterns. In the case of age- and sex-standardised rates for example (see Fig. 5), there appears to be a crescent of high-risk countries beginning in Northern Europe (Iceland, Ireland, Norway and Sweden) that runs through middle Europe (Denmark Belgium, Germany, Switzerland and Austria) and then extends south-eastwards through eastern Europe (Hungary, Czech Republic and Slovakia) and beyond (Oman and Iran). Other high-risk countries (Malta, Argentina and Taiwan) escape this pattern. Hypotheses to explain the heterogeneity in risk will need to take these patterns into account.

The present study also reports the heterogeneity in fracture probability for 45 countries and/or ethnic groups with a FRAX model available. Probability is computed from the hazards of death and fracture and differs fundamentally from incidence-a point often unrecognised [32]. FRAX computes probabilities for individuals and not (normally) for a nation so that, for the expression of fracture probability, we chose a clinical scenario of an individual with a prior fragility fracture and a femoral neck T-score for BMD of -2.5 SD. The choice of scenario is somewhat arbitrary but of clinical relevance. We chose the age of 65 years in order to avoid a marked effect of the death risk on the estimate of probability. The 10 -year probability of a 'major osteoporotic fracture' (hip, clinical spine, forearm and humerus) varied markedly in the different countries. As in the case of hip fracture incidence, there was a greater than 10 -fold range in fracture probability. There was some, though not complete, concordance between FRAX-based probabilities and hip fracture incidence reflecting, in part, the effect of the heterogeneity of mortality in different regions $[3,14]$.

Although probability estimates were lower in men than in women, the difference was modest (lower by $23 \%$ ) compared to the twofold difference in agestandardised hip fracture risk. The closer approximation between sexes for the probability estimate arises because the risk of hip and other osteoporotic fractures is more or less identical in men and women of the same age and femoral neck BMD [33-35]. The clinical scenario chosen incorporated a BMD (as well as a prior fragility fracture). The somewhat higher probability estimates in women reflects mainly the lower death risk in women compared with men.

There are many well-recognised limitations in this type of analysis, particularly for register studies that include selection bias, the over identification of cases (double counting), inaccurate reporting or coding of fractures and errors in the denominator catchment population, particularly in regional rather than national studies. The question arises to what extent might heterogeneity of risk be accounted for by these artefacts. Several considerations suggest that these errors, though significant, have a minor effect in explaining the heterogeneity in a worldwide perspective. For example, a large prospective study undertaken in 14 regions in six different countries in Europe using standardised methodology demonstrated variability in hip fracture incidence of the same magnitude as that reported in the present study [9]. Analysis of the potential errors of any one estimate was $\pm 10 \%$, which pales into insignificance against the $1,000 \%$ differences in fracture risk. This study was a regional study but national register studies in Europe have shown similar findings [31].

Another limitation is the assumption that regional estimates of hip fracture risk are representative of the country in question. In addition to large variations in fracture rates around the world, fracture rates may vary within countries. In addition to ethnic-specific differences $[3,12,13,30]$, up to twofold differences in hip fracture incidence have been reported using common methodology with higher rates in urban communities than rural areas in Argentina [36], Turkey [9], Sweden [37], Norway [38-40], Switzerland [41], Croatia [23] and in USA [42, 43]. The concern is perhaps less where several regional 
estimates have been used. In the present study, the majority of studies chosen $(60 \%)$ were national rather than regional estimates. In further 10 countries, the regional estimate was consistent with other regional estimates made within a few years (Argentina, China, Iran, Malaysia, Morocco, Norway, Poland, Sweden, Thailand and UK). In five countries with multiple regional surveys, we used a mean value where studies were of comparable quality (Brazil, Croatia, Greece, Spain and Russia). This left 11 regional surveys (18\% of countries) where we had to rely on a single regional estimate. The analysis of national rather than regional data did not alter our principal findings.

Notwithstanding, in some regions of the world, not all hip fracture cases come to medical attention. The risk estimate for Russia took this into account [26], but the problem has also been identified in other countries (not included in the present study). The underreporting of hip fracture cases has been observed in Georgia (75\% not hospitalised), Kazakhstan (50\% not hospitalised), Kyrgyzstan (50\% not hospitalised) and Moldova (uncertain proportion) [44]. The likely reason is that facilities for surgical management are limited so that hospital admission is not required. Moreover, patients are required to pay for their prosthesis. Thus substantial errors may arise that lead to underreporting of hip fracture cases.

In addition to the large geographic variation reported in the incidence of hip fracture throughout the world, the ageand sex-specific incidence of fracture is changing. This has been well characterised for hip fracture but also noted at other sites of fracture $[45,46]$. Estimates of incidence trends have varied widely and variously reported an increase, plateau and decrease, in age-adjusted incidence rates for hip fracture among both men and women. Studies in Western populations, whether in North America, Europe or Oceania, have generally reported increases in hip fracture incidence through the second half of the last century, but those studies continuing to follow trends over the last two decades have found that rates stabilise, with age-adjusted decreases being observed in certain centres. In contrast, the mortality hazard has continued to decrease in most regions of the world. In other countries (e.g. Japan, China, Turkey, Mexico and Hispanic Americans from California), age-adjusted hip fracture rates continue to rise $[15,47-50]$. In the majority of countries, there is scanty information available. Thus both national and regional estimates undertaken several years ago may not be representative of current risks. Again, it is useful to place this in perspective. Just over half the studies in the present study (52\%) were conducted in 2005 or thereafter and a further $28 \%$ at or after the year 2000 (see Tables 4,5 , and 6 of the Appendix). On average, secular changes approximate $1 \%$ per annum [44, 46, 47] and if operative are likely to introduce accuracy errors of $10 \%$ or less. All these considerations indicate that there are multiple sources of error inherent in this type of analysis but that their magnitude does not undermine the principal finding of 10-fold differences in the risk of hip fracture risk and in 10-year fracture probability worldwide.

The question arises why fracture risk varies so much. The reasons are not known. The trends in incidence strongly suggest environmental rather than genetic factors. This view is supported by changes in risk in immigrant populations. For example, Blacks in USA have lower fracture probabilities than Caucasians, but the incidence of hip fracture in US Blacks is much higher than in African Blacks [12, 13]. A similar 'acclimatisation' is seen in the Japanese population of Hawaii [51] and the higher fracture probabilities among Chinese living in Hong Kong and Singapore compared with mainland China (see Table 7 of the Appendix).

Many risk factors for osteoporosis, and in particular for hip fracture, have been identified which include a low body mass index, low BMD, low calcium intake, reduced sunlight exposure, early menopause, smoking, alcohol consumption, physical activity levels, migration status obesity and, somewhat unexpectedly, obesity. These may have important effects within communities but do not explain differences in risk between communities [9]. The factor which best predicts this is socioeconomic prosperity that in turn may be related to low levels of physical activity or an increased probability of falling on hard surfaces [8]. This is plausible, but only a hypothesis. Paradoxically, socioeconomic prosperity may protect against hip fractures within countries [52]. The contrast between ecological and population risk factors is not uncommon and in the context of hip fracture, for example, is noted with calcium nutrition where countries with the higher calcium intakes have the greater hip fracture risk $[53,54]$. It will be important to determine whether these and other factors are causally related to the heterogeneity of fracture risk. If such factors can be identified and are reversible, the primordial prevention of hip fracture might be feasible in those communities with presently low rates.

Acknowledgments This paper was reviewed and endorsed by the Committee of Scientific Advisors of the International Osteoporosis Foundation and we thank the Committee for their helpful review. We are grateful to the many researchers who have supplied supplementary or unpublished data for this study. These include M Morosano (Argentina), Peter Ebeling P (Australia), M Hiligsmann (Belgium), W Leslie (Canada), Pablo Riedemann and Oscar Neira (Chile), Xu Ling, Weibo Xia, S Cummings (China), B Abrahamsen (Denmark), $\mathrm{CH}$ Orces (Ecuador), R Sund and H Kroger (Finland), Kristin Siggeirsdottir and Vilmundur Gudnason (Iceland), D Dhanwal and C Cooper (India), Errol Hutagalung and Gunawan Tirtarahardja (Indonesia), Carmel Silke, Bryan Whelan, Bernie McGowan (Ireland), Efteem Azar (Jordan), Marija Tamulaitiené and Vidmantas Alekna (Lithuania), A Schembri (Malta), Abdellah El Maghraoui (Morocco), Julie Li-Yu (Philippines), Edward Czerwinsi and Roman Lorenc (Poland), Daniel Grigorie (Romania), Olga Yershova and Olga Lesnyak (Russian Federation), Siok Bee Chionh and Derrick Heng (Singapore), P Masaryk (Slovakia), Leith Zakraoui (Tunisia), G Riera-Espinoza (Venezuela).

Conflicts of interest None. 


\section{Appendix}

Table 3 Studies used to compute age-standardised hip fracture incidence

\begin{tabular}{|c|c|}
\hline Country & Citation \\
\hline Argentina & $\begin{array}{l}\text { Morosano M, Masoni A, Sánchez A (2005) Incidence of hip fractures } \\
\text { in the city of Rosario, Argentina. Osteoporos Int 16: 1339-1344 }\end{array}$ \\
\hline Australia & $\begin{array}{l}\text { Crisp A, Dixon T, Jones, Ebeling P, Cumming R (2012) Declining } \\
\text { incidence of osteoporotic hip fracture in Australia. Manuscript in } \\
\text { preparation }\end{array}$ \\
\hline \multirow[t]{3}{*}{ Austria } & Dimai H P (2008) Personal communication \\
\hline & Dimai HP, Svedbom A, Fahrleitner-Pammer A, et al. (2011) \\
\hline & $\begin{array}{l}\text { Epidemiology of hip fractures in Austria: evidence for a } \\
\text { change in the secular trend. Osteoporos Int22: 685-692 }\end{array}$ \\
\hline Belgium & Hiligsmann M, personal communication, June 2011 \\
\hline \multirow[t]{4}{*}{ Brazil } & $\begin{array}{l}\text { Silveira C, Medeiros M, Coelho-Filho JM et al. (2005) Incidência } \\
\text { de fratura do quadril em area urbana do Nordeste brasileiro. } \\
\text { Cad. Saúde Pública. 21: } 907-912\end{array}$ \\
\hline & $\begin{array}{l}\text { Komatsu RS, Ramos LR, Szejnfeld A (2004) Incidence of proximal } \\
\text { femur fractures in Marilia, Brazil. J Nut Health Aging. 8: } 362\end{array}$ \\
\hline & $\begin{array}{l}\text { Shwartz AV, Kelsey JL, Maggi S et al. (1999) International variation } \\
\text { in the incidence of hip fractures: cross-national project on osteoporosis } \\
\text { for the World Health Organization Program for Research on Aging. } \\
\text { Osteoporos Int 9: } 242-253\end{array}$ \\
\hline & $\begin{array}{l}\text { Castro da Rocha FA, Ribeiro AR (2003) Low incidence of hip } \\
\text { fractures in an equatorial area. Osteoporos Int 14:496-499 }\end{array}$ \\
\hline \multirow[t]{2}{*}{ Canada } & $\begin{array}{l}\text { Leslie WD, O'Donnell S, Lagacé C et al. (2010) Osteoporosis } \\
\text { surveillance expert working group. Population-based Canadian } \\
\text { hip fracture rates with international comparisons. Osteoporos } \\
\text { Int. 21: } 1317-1322\end{array}$ \\
\hline & $\begin{array}{l}\text { Leslie WD, Lix LM, Langsetmo L et al. (2011) Construction of a } \\
\text { FRAX® model for the assessment of fracture probability in Canada } \\
\text { and implications for treatment. Osteoporos Int 22: } 817-827\end{array}$ \\
\hline Chile & Pablo Riedemann and Oscar Neira, personal communication 4th Oct 2011 \\
\hline \multirow[t]{5}{*}{ China } & $\begin{array}{l}\text { Schwartz AV, Kelsey JL, Maggi S et al. (1999) International variation in } \\
\text { the incidence of hip fractures: cross-national project on osteoporosis } \\
\text { for the World Health Organization Program for Research on Aging. } \\
\text { Osteoporos Int 9: } 242-253\end{array}$ \\
\hline & $\begin{array}{l}\text { Ling X, Aimin, L, Xihe Z, Xaioshu C, Cummings SR (1996) Very } \\
\text { low rates of hip fracture in Beijing, Peoples Republic of China. } \\
\text { The Beijing Osteoporosis Project. Am J Epidemiol 144; 901-907 }\end{array}$ \\
\hline & Yan L, Zhou B, Prentice A, Wang X, Golden MH (1999) \\
\hline & Epidemiological study of hip fracture in Shenyang, People's \\
\hline & Penublis of Ching Pone 24.151 155 \\
\hline
\end{tabular}

Zhang L, Cheng A, Bai Z, Lu Y, Endo N, Dohmae Y, Takahashi HE (2000) Epidemiology of cervical and trochanteric fractures of the proximal femur in 1994 in Tangshan, China. J Bone Miner Metab 18: 84-88

Xia W-B, He SL, Xu L et al. (2011) Rapidly increasing rates of hip fracture in Beijing, China J Bone Miner Res. Sep 28. doi: 10.1002/jbmr.519

Colombia Juan Jose Jaller (2009), personal communication

Croatia Matković V, Kostial K, Simonović I, Buzina R, Brodarec A, Nordin BE (1979) Bone status and fracture rates in two regions of Yugoslavia. Am J Clin Nutr. 32: 540-549

Karacić TP, Kopjar B (2009) Hip fracture incidence in Croatia in patients aged 65 years and more. Lijec Vjesn. 2009; 131: 9-13

Czech Stepan JJ, Vaculik J, Pavelka K, Zofka J, Johansson H, Kanis JA (2012) Hip fracture incidence between years 1981 and 2009 and construction of a FRAX ${ }^{\circledR}$ model for the assessment of fracture probability in the Czech Republic. Calcif Tiss Int, (in press)
Notes

Supplementary information from authors

Supplementary information from Australian Institute of Health and Welfare

Supplementary information Statistic Austria

Update of FRAX model with more extensive data Average taken of all data from Brazil

Supplementary information from WB Leslie

Source: Health Ministry, June 2010

Mean of Schwartz 1999, Ling 1996, Yan 1999 and Zhang 2000 used in FRAX model

Xia 2011 used for hip fracture incidence with supplementary data from S Cummings 2011 Survey of all (five) hospitals in region

Mean incidence derived from two regions in Matković 1979 (Podravina Podravina and Istra) and national data in Karacić 2009

Additional data, Jan Stepan, personal communication, 2011 
Table 3 (continued)

\begin{tabular}{|c|c|c|}
\hline Country & Citation & Notes \\
\hline Denmark & $\begin{array}{l}\text { Abrahamsen B, Vestergaard P (2010) Declining incidence of hip } \\
\text { fractures and the extent of use of anti-osteoporotic therapy in } \\
\text { Denmark 1997-2006. Osteoporosis Int } 21: 373-80\end{array}$ & $\begin{array}{l}\text { Additional data from the Danish Nati } \\
\text { Board of Health, accessed October }\end{array}$ \\
\hline Ecuador & $\begin{array}{l}\text { Orces CH (2009) Epidemiology of hip fractures in Ecuador. Rev } \\
\text { Panam Salud Publica. 25: 438-442. PMID: } 19695134\end{array}$ & Additional data supplied by author \\
\hline Estonia & $\begin{array}{l}\text { Haviko T, Maasalu K, Seeder J (1996) The incidence of osteoporotic } \\
\text { fractures at the University Hospital of Tartu, Estonia. Scand J } \\
\text { Rheumatol Suppl. 103: 13-15 }\end{array}$ & Data available on women only \\
\hline Finland & Kröger H (2008) Personal communication & $\begin{array}{l}\text { Additional data from Reijo Sund, } \\
\text { National Research and Developmen } \\
\text { Centre for Welfare and Health }\end{array}$ \\
\hline France & $\begin{array}{l}\text { Couris CM, Chapurlat RD, Kanis JA et al. (2011) FRAX® } \\
\text { probabilities and risk of major osteoporotic fracture in France. } \\
\text { Osteoporos Int, Dec 17. [Epub ahead of print] PMID: } 22179418\end{array}$ & \\
\hline Germany & $\begin{array}{l}\text { Icks A, Haastert B, Wildner M, Becker C, Meyer G (2008) Trend } \\
\text { of hip fracture incidence in Germany 1995-2004: a } \\
\text { population-based study. Osteoporos Int 19: 1139-1145 }\end{array}$ & \\
\hline \multirow[t]{2}{*}{ Greece } & $\begin{array}{l}\text { Dretakis EK, Giaourakis G, Steriopoulos K (1992) Increasing } \\
\text { incidence of hip fracture in Crete. Acta Orthop Scand. 63: 150-151 } \\
\text { Paspati I, Galanos A, Lyritis GP (1998) Hip fracture epidemiology } \\
\text { in Greece during 1977-1992. Calcif Tissue Int 62: 542-547 }\end{array}$ & Mean of three studies used \\
\hline & $\begin{array}{l}\text { Elffors I, Allander E, Kanis JA, et al. (1994) The variable incidence } \\
\text { of hip fracture in southern Europe: the MEDOS Study. Osteoporos } \\
\text { Int 4: } 253-263\end{array}$ & \\
\hline Hong Kong & $\begin{array}{l}\text { Tsang SWY, Kung AWC. Kanis JA, Johansson H, Oden A (2009) } \\
\text { Ten-year fracture probability in Hong Kong southern Chinese according } \\
\text { to age and BMD femoral neck T-scores. Osteoporos Int. 20: 1939-1945 }\end{array}$ & \\
\hline Hungary & $\begin{array}{l}\text { Péntek M, Horváth C, Boncz I, Falusi Z, Tóth E, Sebestyén A, Májer I, } \\
\text { Brodszky V, Gulácsi L (2008) Epidemiology of osteoporosis related } \\
\text { fractures in Hungary from the nationwide health insurance database, } \\
\text { 1999-2003.Osteoporos Int; 19: 243-249 }\end{array}$ & \\
\hline Iceland & $\begin{array}{l}\text { Kristin Siggeirsdottir and Vilmundur Gudnason, personal } \\
\text { communication, 15th Aug } 2011\end{array}$ & \\
\hline India & $\begin{array}{l}\text { Dhanwal D, Siwach R, Dixit V, Mithal A, Cooper C (2011) } \\
\text { Incidence of hip fracture in Rohtak, North India. Osteoporos } \\
\text { Int } 22 \text { (Suppl 4): S629-S630 }\end{array}$ & $\begin{array}{l}\text { Supplementary information from D } \\
\text { Dhanwal and C Cooper }\end{array}$ \\
\hline Indonesia & $\begin{array}{l}\text { Errol Hutagalung and Gunawan Tirtarahardja, personal } \\
\text { communication, 5th Oct } 2011\end{array}$ & $\begin{array}{l}\text { Data from Department of Health and } \\
\text { Bureau of Statistics, Indonesia }\end{array}$ \\
\hline Iran & $\begin{array}{l}\text { Soveid M, Serati AR, Masoompoor M (2005) Incidence of hip } \\
\text { fracture in Shiraz, Iran. Osteoporos Int 16: 1412-1416 }\end{array}$ & \\
\hline Ireland & $\begin{array}{l}\text { Bernie McGowan Personal communication } 18 \text { Oct } 2011 \\
\text { McGowan, B, Casey M, Silke C, Whelan B, Bennett K (2012) } \\
\text { Hospitalizations for fracture and associated costs between 2000 } \\
\text { and } 2009 \text { in Ireland: a trend analysis. Submitted for publication }\end{array}$ & $\begin{array}{l}\text { Data from The Economic and Social } \\
\text { Research Institute (ESRI) and Irish } \\
\text { Central Statistics Office }\end{array}$ \\
\hline
\end{tabular}

Israel Levine S, Makin M, Menczel J, Robin G, Naor E, Steinberg R (1970) Incidence of Fractures of the Proximal End of the Femur in Jerusalem: A study of ethnic factors. J Bone Joint Surg Am 52:1193-1202

Italy Piscitelli P, Brandi ML, Chitano G, Johannson H, Kanis JA, Black DM (2012) Updated Fracture Incidence Rates for the Italian Version of FRAX®. Osteoporos Int, submitted

Japan Orimo H, Sakata K (2006) The 4th nationwide survey for hip fracture in Japan (in Japanese). Japan Medical Journal 4180: 25-30

Jordan Azar ES Abulmajeed S, Masri BK, Kanis JA (2011) The prevalence of osteoporotic hip fractures in Jordan. Osteoporos Int 22 (Suppl 5): S715

Kuwait Memon A, Pospula WM, Tantawy AY, Abdul-Ghafar S, Suresha A, Al-Rowaih A (1998) Incidence of hip fracture in Kuwait. Int J Epidemiol 27:860-865

Lebanon Sibai AM, Nasser W, Ammar W, Khalife MJ, Harb H, Fuleihan GE (2011) Hip fracture incidence in Lebanon: a national registry-based study with reference to standardized rates worldwide. Osteoporos Int 22: 2499-2506

The different ethnicities amalgamated

Additional data from Efteem Azar, personal communication, 2010

Kuwaiti data i.e., expatriates excluded 
Table 3 (continued)

\begin{tabular}{|c|c|c|}
\hline Country & Citation & Notes \\
\hline Lithuania & Marija Tamulaitienè, Vidmantas Alekna, personal communication 2011 & \\
\hline Malaysia & $\begin{array}{l}\text { Personal communication, } 2010 \text { Siok Bee Chionh and Dr Derrick } \\
\text { Heng, Director of Epidemiology at the Ministry of Health, Singapore }\end{array}$ & Expatriates living in Singapore \\
\hline Malta & $\begin{array}{l}\text { Schembri A. Public Health Medicine, Department of Health } \\
\text { Information and Research 95, G'Mangia Hill, G'Mangia PTA1313 }\end{array}$ & Hospital survey \\
\hline Mexico & $\begin{array}{l}\text { Johansson H, Clark P, Carlos F, Oden A, McCloskey EV, Kanis JA (2011) } \\
\text { Increasing age and sex specific rates of hip fracture in Mexico. } \\
\text { Osteoporos Int. 22: 2359-2364 }\end{array}$ & \\
\hline Morocco & $\begin{array}{l}\text { El Maghraoui A, Koumba BA, Jroundi I, Achemlal L, Bezza A, } \\
\text { Tazi MA (2005) Epidemiology of hip fractures in } 2002 \text { in Rabat, } \\
\text { Morocco. Osteoporos Int 16:597-602 } \\
\text { Abdellah El Maghraoui personal communication, 20th Oct } 2011\end{array}$ & \\
\hline Netherlands & $\begin{array}{l}\text { Lalmohamed, A, Welsing PMJ, Lems WF et al. (2011) Calibration } \\
\text { of FRAX } ® 3.1 \text { to the Dutch population with data on the epidemiology } \\
\text { of hip fractures. Osteoporos Int, doi } 10.1007 / \mathrm{s} 00198-011-1852-2\end{array}$ & Source: National Office for Statistics, \\
\hline New Zealand & $\begin{array}{l}\text { Brown P, McNeill R, Rawan E, Willingale J (2007) The burden of } \\
\text { osteoporosis in New Zealand: 2007-2020. Osteoporosis New } \\
\text { Zealand Inc }\end{array}$ & $\begin{array}{l}\text { Death and fracture hazard of the } \\
\text { white population }\end{array}$ \\
\hline Nigeria & $\begin{array}{l}\text { Adebajo AO, Cooper C, Evans JG (1991) Fractures of the hip } \\
\text { and distal forearm in West Africa and the United Kingdom. Age } \\
\text { Ageing 20: 435-438 }\end{array}$ & \\
\hline Norway & $\begin{array}{l}\text { Emaus N, Olsen LR, Ahmed LA et al. (2011) Hip fractures in a city } \\
\text { in Northern Norway over } 15 \text { years: time trends, seasonal variation } \\
\text { and mortality: the Harstad Injury Prevention Study. Osteoporos } \\
\text { Int 22: 2603-2610 }\end{array}$ & $\begin{array}{l}\text { National data to be shortly available } \\
\text { from H Meyer }\end{array}$ \\
\hline Oman & $\begin{array}{l}\text { Shukla J, Khandekar R (2008) Magnitude and determinants of } \\
\text { osteoporosis in adult population of South Sharqiya region of } \\
\text { Oman. Saudi Med J 29: } 984-988\end{array}$ & \\
\hline Philippines & Julie Li-Yu (2010) Personal communication & $\begin{array}{l}\text { Insurance claims data for a segment } \mathrm{o} \\
\text { the population }\end{array}$ \\
\hline Poland & $\begin{array}{l}\text { Czerwiński E, Kanis JA, Osieleniec J et al. (2011) Evaluation of } \\
\text { FRAX to characterize fracture risk in Poland. Osteoporos } \\
\text { Int 22: 2507-2512 } \\
\text { Jaworski M, Lorenc RS (2007) Risk of hip fracture in Poland. } \\
\text { Med Sci Monit 13:206-210 }\end{array}$ & $\begin{array}{l}\text { Supplementary information from Edw } \\
\text { Czerwinski and Roman Lorenc, } 201\end{array}$ \\
\hline Portugal & $\begin{array}{l}\text { de Pina MF, Alves SM, Barbosa M, Barros H (2008) Hip fractures } \\
\text { cluster in space: an epidemiological analysis in Portugal. } \\
\text { Osteoporos Int 19:1797-1804 }\end{array}$ & \\
\hline Romania & Daniel Grigorie, 2011 Personal communication & $\begin{array}{l}\text { National hospital discharge register } \\
\text { (National School of Public Health) }\end{array}$ \\
\hline Russia & $\begin{array}{l}\text { Lesnyak O, Ershova O, Belova K et al. (2012). The development } \\
\text { of a FRAX model for the Russian Federation. Submitted Arch } \\
\text { Osteoporos }\end{array}$ & $\begin{array}{l}\text { Combined data 2008-2010 from } \\
\text { Yaroslavl and Pervouralsk }\end{array}$ \\
\hline
\end{tabular}

Olga Yershova, Olga Lesnyak, personal communication, 2010

S Africa Solomon L. Osteoporosis and fracture of the femoral neck in the South African Bantu (1968) J Bone Joint Surg 50: 1-13

S Korea Lim S, Koo BK, Lee EJ et al. (2008) Incidence of hip fractures in Korea. J Bone Miner Metab 26:400-405

Saudi Arabia Al-Nuaim AR, Kremli M, Al-Nuaim M, Sandkgi S (1995) Incidence of proximal femur fracture in an urbanized community in Saudi Arabia. Calcif Tissue Int. 56: 536-538

Serbia Lesić A, Bumbasirević M, Jarebinski M, Pekmezovic T (2005) Incidence of hip fractures in the population of Belgrade during the period 1990-2000. Projections for 2020. Acta Chir Iugosl 52: 95-99

Singapore Siok Bee Chionh and D Heng D Personal communication, 2009

Slovakia Masaryk P, Piestany, Slovakia personal communication 2010

Slovenia Dzajkovska B, Wertheimer AI, Mrhar A (2007) The burden-of-illness study on osteoporosis in the Slovenian female population.

Pham World Sci 29: 404-411

Bantu population

Source: Heng D, Director of Epidemiology, Ministry of Health.

Source: National Institute of Rheumatic Diseases Data available for women only 
Table 3 (continued)

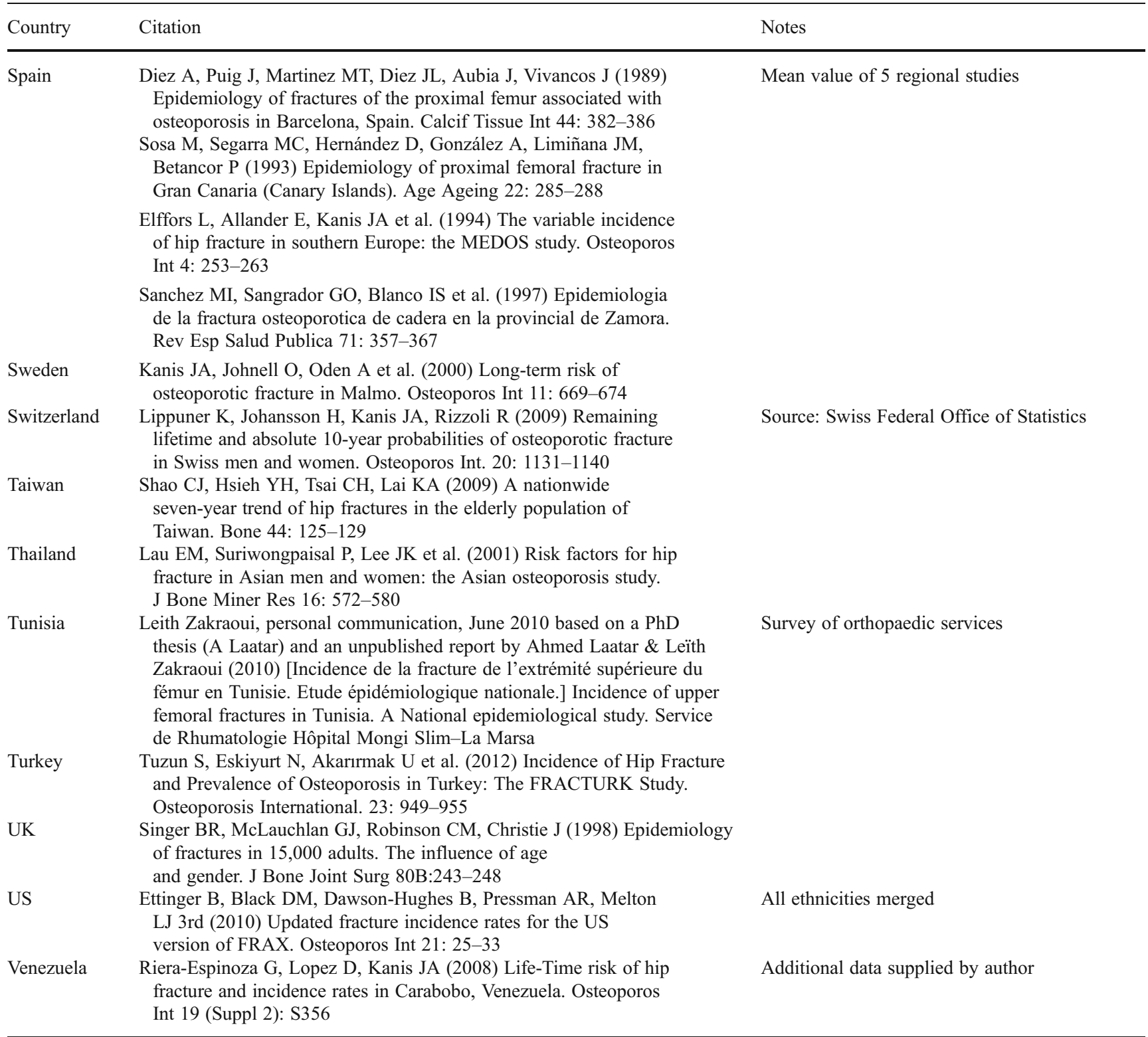

Table 4 Categorisation and colour coding for world standardised annual hip fracture rates $(/ 100,000)$ in men, women and both sexes combined

\begin{tabular}{llccc}
\hline & & & \multicolumn{2}{c}{ Incidence/100,000 } \\
Colour & Category & Women & Men & Men and women \\
\hline Red & High & $>300$ & $150+$ & $>250$ \\
Orange & Moderate & $200-300$ & $100-150$ & $150-250$ \\
Green & Low & $<200$ & $<100$ & $<150$ \\
\hline
\end{tabular}


Table 5 World age-standardised hip fracture rates $(/ 100,000)$ and risk categories

\begin{tabular}{|c|c|c|c|c|c|c|c|c|c|c|c|}
\hline Country & Source & Year & Quality & Catchment & $\begin{array}{l}\text { Selection } \\
\text { criteria }^{a}\end{array}$ & $\mathrm{~F}$ & Risk & M & Risk & $\stackrel{\mathrm{M}+}{\mathrm{F}}$ & Risk \\
\hline Argentina & Morosano et al, 2005 & 2001-2002 & G & $\mathrm{R}$ & $1,3,7$ & 390 & $\mathrm{H}$ & 124 & M & 264 & $\mathrm{H}$ \\
\hline Australia & $\begin{array}{l}\text { Australian Institute of Health } \\
\text { and Welfare PC }\end{array}$ & $2006-2007$ & G & $\mathrm{N}$ & $1,2,7$ & 252 & M & 105 & M & 183 & M \\
\hline Austria & Dimai 2009 & $2001-2005$ & G & $\mathrm{N}$ & $1,4,7$ & 501 & $\mathrm{H}$ & 246 & $\mathrm{H}$ & 380 & $\mathrm{H}$ \\
\hline Belgium & Hiligsmann 2011 & $2005-2007$ & G & $\mathrm{N}$ & $1,4,7$ & 356 & $\mathrm{H}$ & 169 & $\mathrm{H}$ & 268 & $\mathrm{H}$ \\
\hline \multirow[t]{4}{*}{ Brazil } & Silveira et al. 2005 & 2001-2002 & $P$ & $\mathrm{R}$ & 5 & 199 & L & 77 & L & 141 & L \\
\hline & Castro da Roca 2004 & 1996-2000 & $\mathrm{F}$ & $\mathrm{R}$ & & & & & & & \\
\hline & Schwartz et al. 1999 & 1990-1992 & P/F & $\mathrm{R}$ & & & & & & & \\
\hline & Komatsu et al. 2004 & 1994 & $\mathrm{~F}$ & $\mathrm{R}$ & & & & & & & \\
\hline Canada & Leslie et al. 2010, 2011 & 2005 & G & $\mathrm{N}$ & $1,2,4,7$ & 290 & M & 131 & M & 215 & $\mathrm{H}$ \\
\hline Chile & Riedemann and Neira 2011 & 2006 & G & $\mathrm{N}$ & 3,4 & 207 & M & 85 & L & 149 & L \\
\hline China & Xia 2011 & $2002-2006$ & G & $\mathrm{R}$ & 4,7 & 173 & L & 103 & M & 140 & L \\
\hline Colombia & Jaller 2011 & & $\mathrm{~F}$ & $\mathrm{R}$ & 6 & 127 & L & 78 & L & 104 & $\mathrm{~L}$ \\
\hline \multirow[t]{3}{*}{ Croatia } & Matkovic et al. 1979 & $1968-1973$ & $\mathrm{~F}$ & $\mathrm{R}$ & 5 & 177 & L & 135 & M & 157 & M \\
\hline & Matkovic et al. 1979 & $1968-1973$ & $\mathrm{~F}$ & $\mathrm{R}$ & & & & & & & \\
\hline & Karacic and Kopjar 2009 & 2003 & $P$ & $\mathrm{~N}$ & & & & & & & \\
\hline Czech & Stepan et al. 2012 & 2008-2009 & G & $N$ & $1,6,7$ & 374 & $\mathrm{H}$ & 211 & $\mathrm{H}$ & 297 & $\mathrm{H}$ \\
\hline Denmark & Abrahamsen et al. 2010 & 2004 & G & $\mathrm{N}$ & $1,2,7$ & 574 & $\mathrm{H}$ & 290 & $\mathrm{H}$ & 439 & $\mathrm{H}$ \\
\hline Ecuador & Orces 2009 & 2005 & $F / G$ & $\mathrm{~N}$ & 1,7 & 73 & L & 35 & L & 55 & L \\
\hline Estonia & Haviko et al. 1996 & 1991-1994 & $\mathrm{P}$ & $\mathrm{R}$ & 6 & 225 & M & - & & - & \\
\hline Finland & Kröger H 2009 & 2000-2006 & G & $N$ & $1,2,7$ & 293 & M & 180 & $\mathrm{H}$ & 239 & M \\
\hline France & Couris et al. 2011 & 2004 & G & $\mathrm{N}$ & $1,2,4$ & 291 & M & 126 & M & 212 & M \\
\hline Germany & Icks et al. 2008 & 2003-2004 & G & $N$ & $1,2,4$ & 346 & H & 166 & H & 261 & $\mathrm{H}$ \\
\hline \multirow[t]{3}{*}{ Greece } & Dretakis et al.,1992 & 1986 & $\mathrm{~F}$ & $\mathrm{R}$ & 5 & 326 & $\mathrm{H}$ & 158 & H & 247 & M \\
\hline & Paspati et al. 1998 & 1992 & $P$ & $\mathrm{R}$ & & & & & & & \\
\hline & Elffors et al. 1994 & 1988 & G & $\mathrm{R}$ & & & & & & & \\
\hline Hong Kong & Tsang et al. 2009 & $2000-2004$ & G & $\mathrm{N}$ & 1,4 & 324 & $\mathrm{H}$ & 148 & $M$ & 240 & $M$ \\
\hline Hungary & Péntek et al. 2008 & 1999-2003 & G & $\mathrm{N}$ & 1,2 & 367 & H & 206 & H & 291 & H \\
\hline Iceland & $\begin{array}{l}\text { Siggeirsdottir and Gudnason } \\
2010\end{array}$ & 2008 & G & $N$ & $1,2,3,4$ & 385 & $H$ & 150 & $\mathrm{H}$ & 273 & $\mathrm{H}$ \\
\hline India & Dhanwal et al. 2011 & 2009 & G & $\mathrm{R}$ & 6 & 159 & L & 109 & M & 135 & L \\
\hline Indonesia & $\begin{array}{l}\text { Hutagalung and Tirtarahardja } \\
2011\end{array}$ & $2007-2010$ & G & $\mathrm{R}$ & 2,6 & 173 & L & 59 & L & 119 & L \\
\hline Iran & Soveid et al. 2005 & $2000-2003$ & $\mathrm{~F}$ & $\mathrm{R}$ & 3 & 402 & $\mathrm{H}$ & 269 & $\mathrm{H}$ & 339 & $\mathrm{H}$ \\
\hline Ireland & McGowan et al. 2011 & 2008-2010 & G & $\mathrm{N}$ & 2 & 406 & $\mathrm{H}$ & 191 & $\mathrm{H}$ & 304 & $\mathrm{H}$ \\
\hline
\end{tabular}

$H$ high, $M$ moderate, $L$ low (see table above for thresholds of risk), $G$ good, $F$ fair, $P$ poor, $N$ national, $R$ regional, 1 FRAX model available, 2 national rather than regional data, 3 higher quality than other studies, 4 most recent study, 5 mean of several regional estimates, 6 sole study available, 7 additional details supplied by the author, see notes in tables

a Selection criteria—see "Methods" 
Table 5 (continued)

\begin{tabular}{|c|c|c|c|c|c|c|c|c|c|c|c|}
\hline Country & Source & Year & Quality & Catchment & $\begin{array}{l}\text { Selection } \\
\text { criteria }^{a}\end{array}$ & $\mathrm{~F}$ & Risk & M & Risk & $\begin{array}{c}\mathrm{M}+ \\
\mathrm{F}\end{array}$ & Risk \\
\hline Israel & Levine et al. 1970 & 1957-1966 & $\mathrm{F}$ & $\mathrm{R}$ & 6 & 265 & M & 131 & M & 201 & M \\
\hline Italy & Piscitelli et al. 2011 & 2007 & G & $\mathrm{N}$ & $1,2,7$ & 334 & $\mathrm{H}$ & 140 & M & 242 & M \\
\hline Japan & Orimo and Sakata 2006 & 2002 & G & $\mathrm{N}$ & 1 & 266 & M & 165 & H & 218 & M \\
\hline Jordan & Azar et al. 2011 & 2008 & G & $\mathrm{N}$ & 1,6 & 198 & $\mathrm{~L}$ & 114 & M & 158 & M \\
\hline Kuwait & Memon et al. 1998 & 1992-1998 & $\mathrm{F}$ & $\mathrm{R}$ & 6 & 236 & M & 174 & H & 207 & M \\
\hline Lebanon & Sibai et al. 2011 & 2007 & G & $\mathrm{N}$ & $1,3,4$ & 315 & $\mathrm{H}$ & 114 & M & 196 & $\mathrm{M}$ \\
\hline Lithuania & Tamulaitienè and Alekna 2011 & 2010 & $\mathrm{~F}$ & $\mathrm{~N}$ & 6 & 270 & M & 156 & $\mathrm{H}$ & 216 & M \\
\hline Malaysia & Chionh and Heng 2010 & 2007-2009 & G & $\mathrm{R}$ & 3,4 & 269 & M & 114 & M & 205 & M \\
\hline Malta & Schembri 2010 & $2003-2007$ & G & $\mathrm{N}$ & $1,2,4$ & 355 & $\mathrm{H}$ & 160 & $\mathrm{H}$ & 263 & $\mathrm{H}$ \\
\hline Mexico & Johansson et al. 2011 & $2000-2006$ & G & $\mathrm{N}$ & 1,2 & 225 & M & 115 & M & 173 & M \\
\hline Morocco & Al Maghraoui 2011 & 2006-2009 & $\mathrm{P}$ & $\mathrm{R}$ & 4 & 73 & L & 66 & $\mathrm{~L}$ & 69 & L \\
\hline Netherlands & Lalmohamed et al. 2012 & 2005 & G & $\mathrm{N}$ & 1,2 & 249 & M & 121 & M & 188 & M \\
\hline $\begin{array}{l}\text { New } \\
\text { Zealand }\end{array}$ & Brown et al. 2007 & 2003-2005 & G & $\mathrm{N}$ & $1,2,4$ & 288 & M & 140 & M & 218 & M \\
\hline Nigeria & Adebajo et al. 1991 & 1998-1999 & $\mathrm{P}$ & $\mathrm{R}$ & 6 & 2 & L & 2 & L & 2 & L \\
\hline Norway & Emaus et al. 2011 & 1994-2008 & G & $\mathrm{R}$ & 3,4 & 563 & $\mathrm{H}$ & 262 & $\mathrm{H}$ & 420 & $\mathrm{H}$ \\
\hline Oman & Shukla and Khandekar 2008 & 2002-2007 & $\mathrm{F}$ & $\mathrm{R}$ & 6 & 312 & H & 236 & H & 276 & H \\
\hline Philippines & Li-Yu 2010 & 2001-2005 & $\mathrm{F}$ & $\mathrm{N}$ & $1,2,6$ & 133 & $\mathrm{~L}$ & 48 & L & 93 & $\mathrm{~L}$ \\
\hline Poland & Czerwinski and Lorenc 2011 & 2008 & $\mathrm{~F}$ & $\mathrm{R}$ & 1 & 224 & M & 133 & M & 181 & M \\
\hline Portugal & De Pina et al. 2008 & $2000-2002$ & G & $\mathrm{N}$ & 2 & 268 & M & 98 & L & 188 & M \\
\hline Romania & D Grigorie 2011 & 2005-2009 & G & $\mathrm{N}$ & $1,26,7$ & 198 & $\mathrm{~L}$ & 142 & M & 172 & M \\
\hline Russia & Lesnyak et al. 2011 & 2008-2009 & G & $\mathrm{R}$ & 3,4 & 249 & M & 185 & $\mathrm{H}$ & 219 & M \\
\hline$S$ Africa & Solomon 1968 & 1957-1963 & $\mathrm{F}$ & $\mathrm{R}$ & 6 & 20 & $\mathrm{~L}$ & 17 & L & 19 & L \\
\hline S Korea & Lim et al. 2008 & 2001-2004 & G & $\mathrm{N}$ & $1,2,3$ & 268 & M & 176 & $\mathrm{H}$ & 224 & M \\
\hline $\begin{array}{l}\text { Saudi } \\
\text { Arabia }\end{array}$ & Al Nuaim et al. 1995 & 1990-1991 & $\mathrm{F}$ & $\mathrm{R}$ & 6 & 135 & L & 77 & $\mathrm{~L}$ & 107 & L \\
\hline Serbia & Lesic et al. 2005 & 1990-2000 & & & & 184 & & 88 & & 139 & \\
\hline Singapore & Chionh and Heng 2009 PC & 2007-2009 & G & $\mathrm{N}$ & $1,4,7$ & 331 & $\mathrm{H}$ & 156 & $\mathrm{H}$ & 248 & M \\
\hline Slovakia & P Masaryk 2011 PC & 2007 & G & $\mathrm{N}$ & $1,2,6$ & 401 & H & 263 & H & 335 & H \\
\hline Slovenia & Dzajkovska et al. 2007 & 2003 & $\mathrm{~F}$ & $\mathrm{~N}$ & 2,6 & 349 & $\mathrm{H}$ & - & & - & \\
\hline \multirow[t]{5}{*}{ Spain } & Diez et al. 1989 & 1984 & G & $\mathrm{R}$ & 1,5 & 228 & M & 92 & $\mathrm{~L}$ & 164 & M \\
\hline & Sosa et al. 1993 & 1990 & $\mathrm{~F}$ & $\mathrm{R}$ & & & & & & & \\
\hline & Elffors et al. 1994 & 1989 & G & $\mathrm{R}$ & & & & & & & \\
\hline & Elffors et al. 1994 & 1989 & G & $\mathrm{R}$ & & & & & & & \\
\hline & Sanches et al. 1997 & 1991 & $\mathrm{~F}$ & $\mathrm{R}$ & & & & & & & \\
\hline Sweden & Kanis et al. 2000 & 1991 & G & $\mathrm{R}$ & 1,7 & 539 & $\mathrm{H}$ & 247 & $\mathrm{H}$ & 401 & $\mathrm{H}$ \\
\hline Switzerland & Lippuner et al. 2005 and 2009 & 2000 & G & $\mathrm{N}$ & 1,2 & 413 & H & 186 & $\mathrm{H}$ & 306 & H \\
\hline Taiwan & Shao et al. 2009 & 2002 & G & $\mathrm{N}$ & 1 & 392 & $\mathrm{H}$ & 196 & H & 299 & $\mathrm{H}$ \\
\hline Thailand & Lau et al. 2001 & 1997 & $\mathrm{~F}$ & $\mathrm{R}$ & 4 & 203 & M & 91 & $\mathrm{~L}$ & 150 & M \\
\hline Tunisia & Zakraoui 2010 & 2001 & $\mathrm{P}$ & $\mathrm{N}$ & 1,6 & 58 & $\mathrm{~L}$ & 41 & L & 50 & L \\
\hline Turkey & Tuzun et al. 2011 & 2009 & G & $\mathrm{N}$ & 1,2 & 357 & H & 110 & M & 240 & M \\
\hline UK & Singer et al. 1998 & 1992-1993 & G & $\mathrm{R}$ & 1 & 349 & $\mathrm{H}$ & 140 & M & 250 & M \\
\hline us & Ettinger et al. 2010 & year & G & $\mathrm{N}$ & 1 & 260 & M & 122 & M & 195 & M \\
\hline Venezuela & Riera-Espinoza 2008 & 2005-2006 & $\mathrm{F}$ & $\mathrm{R}$ & 6,7 & 150 & $\mathrm{~L}$ & 45 & $\mathrm{~L}$ & 100 & L \\
\hline
\end{tabular}


Table 6 Ethnic-specific rates in USA

\begin{tabular}{lclllllll}
\hline US Asian & 158 & $\mathrm{~L}$ & 92 & $\mathrm{~L}$ & 127 & $\mathrm{~L}$ & $\mathrm{G}$ \\
US Black & 136 & $\mathrm{~L}$ & 76 & $\mathrm{~L}$ & 108 & $\mathrm{~L}$ & $\mathrm{G}$ \\
US Caucasian & 316 & $\mathrm{H}$ & 143 & $\mathrm{M}$ & 234 & $\mathrm{M}$ & $\mathrm{G}$ \\
US Hispanic & 167 & $\mathrm{~L}$ & 84 & $\mathrm{~L}$ & 28 & $\mathrm{~L}$ & $\mathrm{G}$ \\
\hline
\end{tabular}

Table 7 Ten-year probabilities of a major osteoporotic fracture and categories of risk in men and in women with a prior fragility fracture (and no other clinical risk factors) at the threshold of osteoporosis as judged by BMD at the femoral neck (i.e. a T-score of $-2.5 \mathrm{SD}$ )

\begin{tabular}{|c|c|c|}
\hline & $\begin{array}{l}\text { Men } \\
\text { Major }\end{array}$ & $\begin{array}{l}\text { Women } \\
\text { Major }\end{array}$ \\
\hline Tunisia & 1.9 & 2.4 \\
\hline Ecuador $^{\mathrm{a}}$ & 2.5 & 2.9 \\
\hline Philippines & 4.8 & 6.7 \\
\hline China & 5.4 & 6.9 \\
\hline Lebanon $^{\mathrm{a}}$ & 7.0 & 9.1 \\
\hline Colombia & 7.1 & 8.7 \\
\hline US (Black) & 7.2 & 9.8 \\
\hline Spain & 7.4 & 9.0 \\
\hline Australia & 7.8 & 8.8 \\
\hline Poland & 7.9 & 10. \\
\hline New Zealand & 8.9 & 11 \\
\hline Romania & 9.0 & 12 \\
\hline France & 9.2 & 11 \\
\hline Turkey & 9.9 & 12 \\
\hline Jordan & 10 & 12 \\
\hline Netherlands & 10 & 12 \\
\hline US (Asian) & 10 & 12 \\
\hline US (Hispanic) & 10 & 12 \\
\hline Mexico & 10 & 13 \\
\hline Hungary & 10 & 15 \\
\hline Sri Lanka ${ }^{\mathrm{a}}$ & 11 & 14 \\
\hline Finland & 11 & 13 \\
\hline Germany & 11 & 14 \\
\hline Argentina & 11 & 15 \\
\hline South Korea & 11 & 15 \\
\hline Hong Kong & 12 & 14 \\
\hline Italy & 12 & 14 \\
\hline Czech $^{\mathrm{b}}$ & 12 & 16 \\
\hline Singapore Indians & 13 & 15 \\
\hline Japan & 13 & 17 \\
\hline Belgium $^{\mathrm{b}}$ & 13 & 16 \\
\hline Russia $^{\mathrm{a}}$ & 13 & 21 \\
\hline Singapore Chinese & 14 & 16 \\
\hline Singapore Malay & 14 & 16 \\
\hline Canada & 15 & 18 \\
\hline Malta & 15 & 18 \\
\hline UK & 15 & 19 \\
\hline Slovakia $^{\mathrm{a}}$ & 15 & 20 \\
\hline Taiwan & 16 & 19 \\
\hline Austria & 16 & 20 \\
\hline US (Caucasian) & 17 & 21 \\
\hline Switzerland & 18 & 22 \\
\hline Norway $^{\mathrm{a}}$ & 19 & 22 \\
\hline Sweden & 21 & 24 \\
\hline Denmark & 23 & 27 \\
\hline
\end{tabular}

The body mass index was set at $24 \mathrm{~kg} / \mathrm{m}^{2}$. The data are sorted by probability of major fracture in men. Risk category is divided into three: low (red; probability in percent $<10$ ), intermediate (orange; 10 $15)$ and high $(>15)$

${ }^{a}$ New model, online January 2012

${ }^{\mathrm{b}}$ Updated model, online January 2012

\section{References}

1. Ström O, Borgström F, Kanis JA et al (2011) Osteoporosis: burden, health care provision and opportunities in the EU. A report prepared in collaboration with the International Osteoporosis Foundation (IOF) and the European Federation of Pharmaceutical Industry Associations (EFPIA). Arch Osteoporos. doi:10.1007/ s11657-011-0060-1

2. Johnell O, Kanis JA (2006) An estimate of the world-wide prevalence and disability associated with osteoporotic fractures. Osteoporos Int 17:1726-1733

3. Kanis JA on behalf of the World Health Organization Scientific Group (2008) Assessment of osteoporosis at the primary healthcare level. Technical Report. WHO Collaborating Centre, University of Sheffield, UK. Available at http://www.shef.ac.uk/FRAX/ index.htm

4. Kanis JA, Johnell O (2005) Requirements for DXA for the management of osteoporosis in Europe. Osteoporos Int 16:229-238

5. Cheng SY, Levy AR, Lefaivre KA, Guy P, Kuramoto L, Sobolev B (2011) Geographic trends in incidence of hip fractures: a comprehensive literature review. Osteoporos Int 22:2575-2586

6. Bacon WE, Maggi S, Looker A et al (1996) International comparison of hip fracture rates in 1988-89. Osteoporos Int 6:69-75

7. Dhanwal DK, Dennison EM, Harvey NC, Cooper C (2011) Epidemiology of hip fracture: worldwide geographic variation. Indian J Orthop 45:15-22

8. Johnell O, Borgstrom F, Jonsson B, Kanis J (2007) Latitude, socioeconomic prosperity, mobile phones and hip fracture risk. Osteoporos Int 18:333-337

9. Elffors I, Allander E, Kanis JA et al (1994) The variable incidence of hip fracture in southern Europe: the MEDOS study. Osteoporos Int 4:253-263

10. Schwartz AV, Kelsey JL, Maggi S et al (1999) International variation in the incidence of hip fractures: cross-national project on osteoporosis for the World Health Organization Program for Research on Aging. Osteoporos Int 9:242-253

11. Sibai AM, Nasser W, Ammar W, Khalife MJ, Harb H, Fuleihan Gel-H (2011) Hip fracture incidence in Lebanon: a national registry-based study with reference to standardized rates worldwide. Osteoporos Int 22:2499-2506

12. Cauley JA, El-Hajj Fuleihan G, Arabi A et al (2011) Official positions for FRAX ${ }^{\circledR}$ clinical regarding international differences from Joint Official Positions Development Conference of the International Society for Clinical Densitometry and International Osteoporosis Foundation on FRAX ${ }^{\circledR}$. J Clin Densitom 14:240262

13. Cauley JA, El-Hajj Fuleihan G, Arabi A et al (2010) FRAX International Task Force and FRAX International US subgroup report. Resource documents for the IOF/ISCD FRAX Initiative

14. Kanis JA, Johnell O, De Laet C, Jonsson B, Oden A, Ogelsby AK (2002) International variations in hip fracture probabilities: implications for risk assessment. J Bone Miner Res 17:1237-1244

15. Xia WB, He SL, Xu L et al (2012) Rapidly increasing rates of hip fracture in Beijing, China. J Bone Miner Res 27:125-129

16. Johansson H, Kanis JA, McCloskey EV et al (2011) A FRAX ${ }^{\circledR}$ model for the assessment of fracture probability in Belgium. Osteoporos Int 22:453-461

17. Hiligsmann M, Bruyère $O$, Ethgen $O$, Gathon HJ, Reginster JY (2008) Lifetime absolute risk of hip and other osteoporotic fracture in Belgian women. Bone 43:991-994

18. Piscitelli P, Brandi ML, Chitano G, Johannson H, Kanis JA, Black DM (2012) Updated fracture incidence rates for the Italian version of FRAX ${ }^{\circledR}$. Osteoporos Int (in press) 
19. Silveira C, Medeiros M, Coelho-Filho JM et al (2005) Incidência de fratura do quadril em area urbana do Nordeste brasileiro. Cad Saúde Pública 21:907-912

20. Castro da Rocha FA, Ribeiro AR (2003) Low incidence of hip fractures in an equatorial area. Osteoporos Int 14:496-499

21. Komatsu RS, Ramos LR, Szejnfeld (2004) Incidence of proximal femur fractures in Marilia, Brazil. J Nutr Health Aging 8:362

22. Karacić TP, Kopjar B (2009) Hip fracture incidence in Croatia in patients aged 65 years and more. Lijec Vjesn 131:9-13

23. Matković V, Kostial K, Simonović I, Buzina R, Brodarec A, Nordin BE (1979) Bone status and fracture rates in two regions of Yugoslavia. Am J Clin Nutr 32:540-549

24. Dretakis EK, Giaourakis G, Steriopoulos K (1992) Increasing incidence of hip fracture in Crete. Acta Orthop Scand 63:150-151

25. Paspati I, Galanos A, Lyritis GP (1998) Hip fracture epidemiology in Greece during 1977-1992. Calcif Tissue Int 62:542-547

26. Lesnyak O, Ershova O, Belova K et al (2012) The development of a FRAX model for the Russian Federation. Arch Osteoporos (in press)

27. Czerwiński E, Kanis JA, Osieleniec J et al (2011) Evaluation of FRAX to characterize fracture risk in Poland. Osteoporos Int 22:2507-2512

28. Jaworski M, Lorenc RS (2007) Risk of hip fracture in Poland. Med Sci Monit 13:206-210

29. United Nations (2010) Population Division of the Department of Economic and Social Affairs of the United Nations Secretariat, World Population Prospects: Available at http://esa.un.org/unpd/ wpp/unpp/panel_indicators.htm, Accessed November 2011

30. Levine S, Makin M, Menczel J, Robin G, Naor E, Steinberg R (1970) Incidence of fractures of the proximal end of the femur in Jerusalem: a study of ethnic factors. J Bone Joint Surg Am 52:1193-1202

31. Johnell O, Gullberg B, Allander A, Kanis JA (1992) The apparent incidence of hip fracture in Europe. Osteoporos Int 2:298-302

32. Kanis JA, Oden A, Johansson H, McCloskey E (2012) Pitfalls in the external validation of FRAX. Osteoporos Int 23:423-431

33. Johnell O, Kanis JA, Oden A et al (2005) Predictive value of BMD for hip and other fractures. J Bone Miner Res 20:1185-1194, Erratum in: J Bone Miner Res. 2007; 22: 774

34. Kanis JA, Bianchi G, Bilezikian JP, Kaufman JM, Khosla S, Orwoll E, Seeman E (2011) Towards a diagnostic and therapeutic consensus in male osteoporosis. Osteoporos Int 22:2789-2798

35. Srinivasan B, Kopperdahl DL, Amin S et al (2011) Relationship of femoral neck areal bone mineral density to volumetric bone mineral density, bone size, and femoral strength in men and women. Osteoporos Int 23:155-162

36. Wittich A, Bagur A, Mautalen C et al (2010) Epidemiology of hip fracture in Tucuman, Argentina. Osteoporos Int 21:1803-1807

37. Jonsson B, Gardsell P, Johnell O, Redlund-Johnell I, Sernbo I (1992) Differences in fracture pattern between an urban and a rural population: a comparative population-based study in southern Sweden. Osteoporos Int 2:269-273
38. Finsen V, Benum $P$ (1987) Changing incidence of hip fractures in rural and urban areas of central Norway. Clin Orthop Relat Res 218:104-110

39. Bulajic-Kopjar M, Wiik J, Nordhagen R (1998) Regional differences in the incidence of femoral neck fractures in Norway. Tidsskr Nor Laegeforen 118:30-33

40. Kaastad TS, Meyer HE, Falch JA (2008) Incidence of hip fracture in Oslo, Norway: differences within the city. Bone 22:175-178

41. Chevalley T, Herrmann FR, Delmi et al (2002) Evaluation of the age-adjusted incidence of hip fractures between urban and rural areas: the difference is not related to the prevalence of institutions for the elderly. Osteoporos Int 13:113-118

42. Jacobsen SJ, Goldberg J, Miles TP, Brody JA, Stiers W, Rimm AA (1990) Regional variation in the incidence of hip fracture. US white women aged 65 years and older. JAMA 264:500-502

43. Madhok R, Melton LJ 3rd, Atkinson EJ, O'Fallon WM, Lewallen DG (1993) Urban vs. rural increase in hip fracture incidence. Age and sex of 901 cases 1980-89 in Olmsted County, U.S.A. Acta Orthop Scand 64:543-548

44. International Osteoporosis Foundation (2011) The Eastern European and Central Asia Regional Audit: epidemiology, costs and burden of osteoporosis in 2010. International Osteoporosis Foundation, Nyon

45. Cooper C, Cole ZA, Holroyd CR, Earl SC, Harvey NC, Dennison EM, the IOF CSA Working Group on Fracture Epidemiology (2011) Secular trends in the incidence of hip and other osteoporotic fractures. Osteoporos Int 22:1277-1288

46. Gullberg B, Johnell O, Kanis JA (1997) World-wide projections for hip fractures. Osteoporos Int 7:407-413

47. Johansson H, Clark P, Carlos F, Oden A, McCloskey EV, Kanis JA (2011) Increasing age- and sex-specific rates of hip fracture in Mexico: a survey of the Mexican institute of social security. Osteoporos Int 22:2359-2364

48. Zingmond DS, Melton LJ 3rd, Silverman SL (2004) Increasing hip fracture incidence in California Hispanics, 1983 to 2000. Osteoporos Int 15:603-610

49. Tuzun S, Eskiyurt N, Akarirmak U et al (2012) Incidence of hip fracture and prevalence of osteoporosis in Turkey: the FRACTURK study. Osteoporos Int 23:949-955

50. Hagino H, Furukawa K, Fujiwara S et al (2009) Recent trends in the incidence and lifetime risk of hip fracture in Tottori, Japan. Osteoporos Int 20:543-548

51. Ross PD, Norimatsu H, Davis JW et al (1991) A comparison of hip fracture incidence among native Japanese, Japanese Americans, and American Caucasians. Am J Epidemiol 133:801-809

52. Bacon WE, Hadden WC (2000) Occurrence of hip fractures and socioeconomic position. J Aging Health 12:193-203

53. Kanis JA, Passmore R (1989) Calcium supplementation of the dietI. Br Med J 296:137-140

54. Kanis JA, Passmore R (1989) Calcium supplementation of the dietII. Br Med J 296:205-208 